\title{
Testosterone: a metabolic hormone in health and disease
}

\author{
Daniel M Kelly ${ }^{1}$ and T Hugh Jones ${ }^{1,2}$ \\ ${ }^{1}$ Department of Human Metabolism, Medical School, The University of Sheffield, Sheffield S10 2RX, UK ${ }^{2}$ Robert \\ Hague Centre for Diabetes and Endocrinology, Barnsley Hospital NHS Foundation Trust, Gawber Road, Barnsley S75 \\ 2EP, UK
}

Correspondence should be addressed to $\mathrm{T} \mathrm{H}$ Jones Email hugh.jones@nhs.net

\begin{abstract}
Testosterone is a hormone that plays a key role in carbohydrate, fat and protein metabolism. It has been known for some time that testosterone has a major influence on body fat composition and muscle mass in the male. Testosterone deficiency is associated with an increased fat mass (in particular central adiposity), reduced insulin sensitivity, impaired glucose tolerance, elevated triglycerides and cholesterol and low HDL-cholesterol. All these factors are found in the metabolic syndrome (MetS) and type 2 diabetes, contributing to cardiovascular risk. Clinical trials demonstrate that testosterone replacement therapy improves the insulin resistance found in these conditions as well as glycaemic control and also reduces body fat mass, in particular truncal adiposity, cholesterol and triglycerides. The mechanisms by which testosterone acts on pathways to control metabolism are not fully clear. There is, however, an increasing body of evidence from animal, cell and clinical studies that testosterone at the molecular level controls the expression of important regulatory proteins involved in glycolysis, glycogen synthesis and lipid and cholesterol metabolism. The effects of testosterone differ in the major tissues involved in insulin action, which include liver, muscle and fat, suggesting a complex regulatory influence on metabolism. The cumulative effects of testosterone on these biochemical pathways would account for the overall benefit on insulin sensitivity observed in clinical trials. This review discusses the current knowledge of the metabolic actions of testosterone and how testosterone deficiency contributes to the clinical disease states of obesity, MetS and type 2 diabetes and the role of testosterone replacement.
\end{abstract}
Key Words
- metabolism
- testosterone
- type 2 diabetes
- metabolic syndrome

\section{Introduction}

There has been an alarming increase, of epidemic proportions, in both obesity and diabetes in the general population with increased cardiovascular risk associated with type 2 diabetes mellitus (T2DM) and/or metabolic syndrome (MetS). MetS is defined as the presence of at least three of the following components: central obesity, hyperglycaemia (including T2DM), hypertension, hypertriglyceridaemia and low HDL-cholesterol (HDL-C). The MetS, a condition recognised by the World Health Organization, is associated with an increased risk of myocardial infarction, stroke and cardiovascular death. Reduced insulin sensitivity (known as insulin resistance) is the central biochemical defect associated with MetS and T2DM. Central obesity, hepatic steatosis and intracellular fat in muscle cells as well as lack of exercise and genetic factors precipitate the development of insulin resistance. Insulin resistance in turn promotes the development of glucose intolerance, hypertriglyceridaemia, low HDL-C, hypertension,

Published by Bioscientifica Ltd. 
endothelial dysfunction and a proinflammatory milieu, which combine to promote atherogenesis.

Men develop coronary artery disease and experience premature coronary events earlier than women, increasing the risk of cardiovascular mortality by more than twofold. This led to the belief that testosterone per se exerts a detrimental influence upon the cardiovascular system; however, evidence has emerged over recent years to suggest that a number of the cellular mechanisms intimate to the atherosclerotic process are beneficially modulated by testosterone. Indeed, it is well established that total and biologically available testosterone in men decreases with age and the age-associated decline may be related to the increased prevalence of cardiovascular disease (CVD) and comorbidities. In fact, testosterone deficiency has been reported in population studies to be associated with an increase in all-cause mortality, and this has been shown to be accounted for mainly by CVD (Khaw et al. 2007, Vikan et al. 2009, Araujo et al. 2011). Moreover, accumulating evidence suggests that testosterone deficiency is an independent cardiovascular risk factor and many recent reviews have focussed on the link between hypogonadism, MetS, T2DM and CVD (Makhsida et al. 2005, Shabsigh et al. 2008, Yassin et al. 2008, Corona et al. 2009, Diaz-Arjonilla et al. 2009, Jones \& Saad 2009, Stanworth \& Jones 2009, Traish et al. 2009, Zitzmann 2009a, Grossmann et al. 2010, Jones 2010a,b, Muraleedharan \& Jones 2010, Moulana et al. 2011, Wang et al. 2011, Saad et al. 2012, Salam et al. 2012).

Testosterone levels themselves are considered to be lowered by chronic disease, making the designation of a causal relationship difficult to delineate (Morris \& Channer 2012). Androgen deprivation therapy (ADT) as treatment for prostate cancer is a unique situation where the direct effects of lowering testosterone can be observed. While ADT reduces tumour growth and survival, it also increases the risk of coronary heart disease, diabetes and cardiovascular death (Levine et al. 2010, Jones 2011). This supports a key role of testosterone in atheroprotection, noted by a science advisory from the American Heart Association (Levine et al. 2010). Testosterone replacement therapy (TRT) in androgen-deficient men is now slowly being recognised for its therapeutic potential in the management of MetS and T2DM as well as its known benefit on quality of life and sexual health. Remarkably, physiologically replacing testosterone in men with T2DM and low testosterone levels has been demonstrated to significantly improve survival (Muraleedharan et al. 2011, Shores et al. 2012). However, with some confounding results, a lack of long-term placebo-controlled trials and an uncertainty regarding the underlying mechanisms of action, TRT remains controversial and its use as a protective metabolic hormone in CVD is at the centre of great debate. This review focuses on some of the clinical, experimental and mechanistic evidence implicating a role for testosterone in cardio-metabolic disorders.

\section{Testosterone deficiency and metabolic risk}

Testosterone deficiency has a high prevalence in men with T2DM (Dhindsa et al. 2004, Corona et al. 2006, Ding et al. 2006, Kapoor et al. 2007a, Corona et al. 2009). Furthermore, low testosterone is associated with impaired insulin sensitivity, increased percentage of body fat, truncal obesity, dyslipidaemia, hypertension and CVD (see Wang et al. (2011)). Epidemiological studies have consistently reported that up to $40 \%$ of men with T2DM have testosterone deficiency (Dhindsa et al. 2004, Corona et al. 2006, 2009, Ding et al. 2006, Kapoor et al. 2007a). Two recent systematic reviews and meta-analyses support that endogenous total and free testosterone was lower in subjects with MetS compared with those without (Brand et al. 2010, Corona et al. 2011). Several longitudinal studies demonstrate a similar association with a low testosterone concentration independently predicting the future development of insulin resistance, MetS and T2DM (Haffner et al. 1996, Stellato et al. 2000, Oh et al. 2002, Laaksonen et al. 2004, Kupelian et al. 2006, Rodriguez et al. 2007, Selvin et al. 2007, Haring et al. 2009).

The causality of this relationship between low testosterone and metabolic disease is unclear with obesity-induced androgen deficiency and hypogonadism-induced obesity both likely contributing to a bidirectional effect on disease pathology. Indeed, increased body fat is a well-known clinical feature of hypogonadism, and men with MetS at baseline are at an increased risk of developing hypogonadism based on an 11-year follow-up (Laaksonen et al. 2005). The finding that obesity impairs testosterone levels while low testosterone levels promote increased fat deposition was initially proposed as the hypogonadal-obesity cycle hypothesis by Cohen (1999). Testosterone is converted to $17 \beta$ oestradiol $\left(\mathrm{E}_{2}\right)$ by the enzymatic activity of aromatase in adipose tissue. Thus, with higher adipocyte expression of aromatase comes a subsequent reduction of circulating testosterone. Falling testosterone promotes increasing adipocyte number and fat deposition, which gradually leads to a further lowering effect on testosterone levels. In addition, the majority of the normal negative feedback of testosterone on the hypothalamo-pituitary axis occurs

Published by Bioscientifica Ltd 
via its aromatisation (either in peripheral adipose tissue or centrally) to $\mathrm{E}_{2}$ (Hayes et al. 2000, 2001). Therefore, the excess aromatase activity from increased adipocyte numbers in obese men results in the suppression of gonadotrophin-mediated testosterone secretion leading to progressive hypogonadism.

The hypogonadal-obesity-adipocytokine hypothesis (Fig. 1) extends Cohen's theory and explains why the body cannot respond to low testosterone levels by the normal homoeostatic compensatory production of androgens via increased gonadotrophin secretion to stimulate the testis (Jones 2007). $\mathrm{E}_{2}$ and the inflammatory adipocytokines tumour necrosis factor $\alpha(\mathrm{TNF} \alpha)$ and interleukin 6 (IL6) inhibit hypothalamic production of GNRH and subsequent release of LH and FSH from the pituitary. This, in turn, reduces gonadal stimulation and inhibits testosterone release, thus causing a state of hypogonadotrophic hypogonadism. Leptin, an adipose-derived hormone with a well-known role in regulation of body weight and food intake, also induces LH release under normal conditions via stimulation of hypothalamic GNRH neurons. GNRH neurons, however, exhibit little or no mRNA for leptin receptors (Finn et al. 1998). Kisspeptins are peptides secreted by specific neurons in the hypothalamus and may provide the functional link between leptin and downstream gonadal regulation as they play a central role in the modulation of GNRH secretion and subsequent $\mathrm{LH}$ release. Indeed, GNRH neurons in the hypothalamus possess the kisspeptin receptor and kisspeptin neurons express the leptin receptor (Roseweir \& Millar 2009). In human obesity, whereby adipocytes are producing elevated amounts of leptin, the hypothalamicpituitary axis becomes leptin resistant (Isidori et al. 1999, Mantzoros 1999). In addition, oestrogen receptors (ERs)

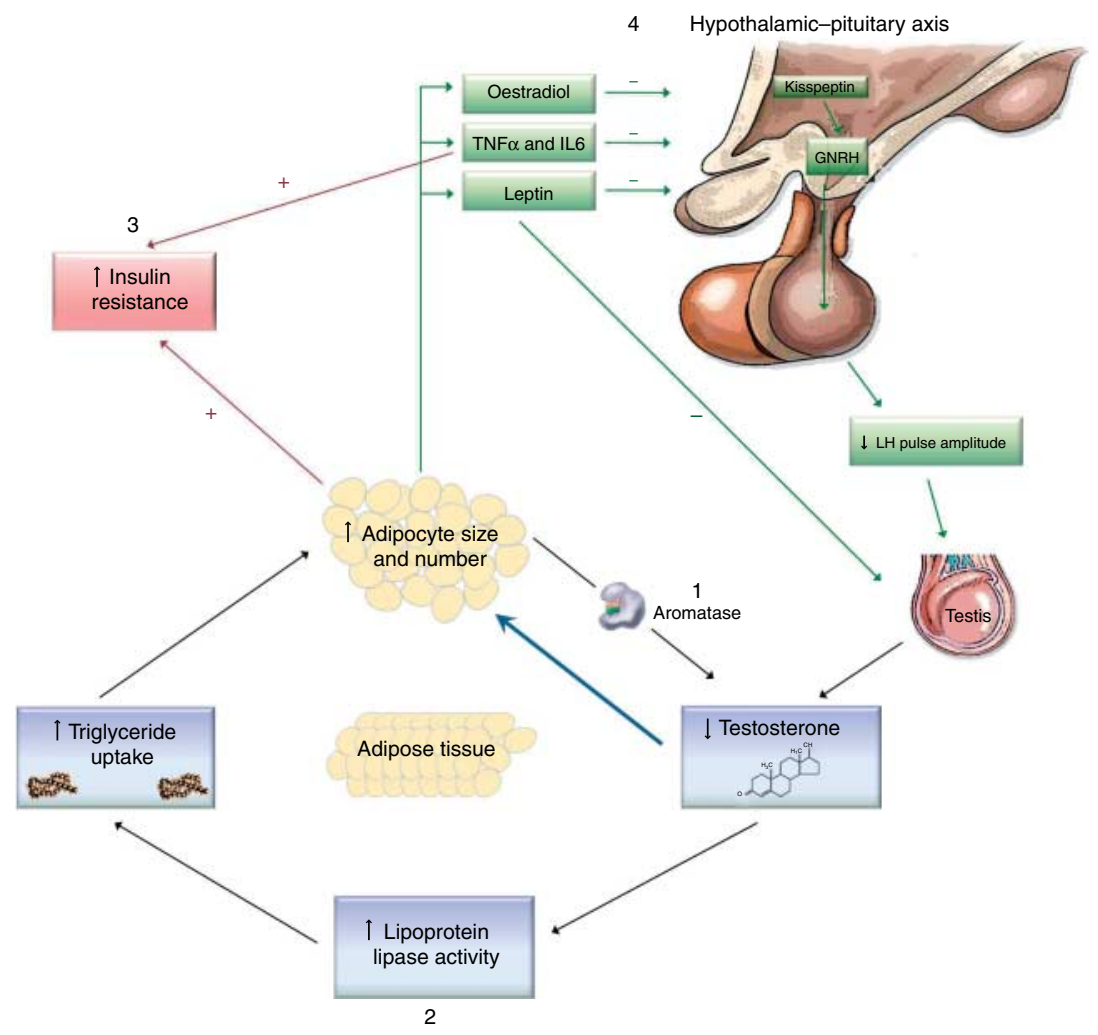

\section{Figure 1}

The hypogonadal-obesity-adipocytokine hypothesis. High aromatase activity in adipocytes converts testosterone to oestradiol (1). Reduced tissue testosterone facilitates triglyceride storage in adipocytes by allowing increased lipoprotein lipase activity (2) and stimulating pluripotent stem cells to mature into adipocytes (blue arrow). Increased adipocyte mass is associated with greater insulin resistance (3). Oestradiol and adipocytokines TNF $\alpha$, IL6 and leptin (as a result of leptin resistance in human obesity) inhibit the hypothalamic-pituitary-testicular axis response to decreasing androgen levels (4). Kisspeptin neurons are inhibited by oestradiol, inflammation and leptin resistance and thus reduce GNRH stimulation of the pituitary and subsequent LH release. Reduced LH pulse decreases gonadal stimulation and testosterone release, thus causing a state of hypogonadotrophic hypogonadism. Furthermore, leptin also directly inhibits the stimulatory action of gonadotrophins on the Leydig cells of the testis to decrease testosterone production. + , positive effect; - , negative effect (Jones 2010a,b). 
are demonstrated on kisspeptin neurons and there is evidence from animal studies that leptin resistance, inflammation and oestrogens inhibit neuronal release of kisspeptin (see George et al. (2010)). Beyond hypothalamic action, leptin also directly inhibits the stimulatory action of gonadotrophins on the Leydig cells of the testis to decrease testosterone production; therefore, elevated leptin levels in obesity may further diminish androgen status (Isidori et al. 1999). Moreover, increasing insulin resistance assessed by glucose tolerence test and hypoglycemic clamp was shown to be associated with a decrease in Leydig cell testosterone secretion in men (Pitteloud et al. 2005a).

ADT for the treatment of prostatic carcinoma in some large epidemiological studies has been shown to be associated with an increased risk of developing MetS and T2DM (Keating et al. 2006, Levine et al. 2010). Non-diabetic men undergoing androgen ablation show increased occurrence of new-onset diabetes and demonstrate elevated insulin levels and worsening glycaemic control (Keating et al. 2006, Derweesh et al. 2007). Prostate cancer patients with pre-existing T2DM show a further deterioration of insulin resistance and worsening of diabetic control following ADT (Haider et al. 2007). Indeed, a review of cross-sectional studies of men undergoing long-term ( $>12$ months) ADT over the last 20 years reveals a higher prevalence of diabetes and MetS compared with controls (Shahani et al. 2008). The authors conclude that abdominal obesity and hyperglycaemia in relation to low testosterone were responsible for this higher prevalence, predisposing ADT patients to higher cardiovascular risk.

\section{Testosterone therapy}

Testosterone administration was first shown to improve glucose disposal and lower plasma insulin levels over a 3-month period in obese men (Mårin et al. 1992a). A follow-on study over 8 months by the same group confirmed that testosterone therapy in men with central obesity reduced insulin resistance as assessed using euglycaemic-hyperinsulinaemic clamp studies (Mårin et al. 1992b). TRT was first shown to improve insulin resistance in hypogonadal men with T2DM in 2006. Kapoor et al. (2006, 2007a) reported the first randomised double-blind placebo-controlled crossover study of testosterone therapy in hypogonadal men with T2DM. Once fortnightly i.m. injections of $200 \mathrm{mg}$ testosterone esters over 3 months resulted in significant improvement in insulin sensitivity and glycaemic control (HbA1c $-0.37 \%$ ) as well as a reduction in waist circumference, serum leptin and total cholesterol. The testosterone replacement in men with metabolic syndrome or type 2 diabetes (TIMES2) study, a large multi-centre European randomised double-blind placebo-controlled trial $(n=220)$, demonstrated that testosterone replacement (2\% testosterone gel) in hypogonadal men improved insulin resistance after 6 and 12 months of therapy by 15 and $16 \%$ compared with placebo (Jones et al. 2011). It is important to recognise that this benefit is similar to that of metformin, a first-line drug in the treatment of T2DM. Both the TIMES2 and the Moscow studies (randomised doubleblind placebo-controlled trial; $n=184 ; 30$-week duration; intramuscular testosterone undecanoate) showed significant benefits on insulin resistance in men with the MetS (Kalinchenko et al. 2010, Jones et al. 2011).

Testosterone replacement has also been demonstrated to improve glycaemic control in some other studies in men with uncontrolled diabetes but these were not placebo controlled (Boyanov et al. 2003, Heufelder et al. 2009). One of these trials did compare the effects of a diet and exercise programme with the same programme in combination with testosterone replacement in hypogonadal newly diagnosed men with T2DM (Heufelder et al. 2009). This study found a greater benefit on glycaemic control with testosterone replacement than those with diet and exercise alone. The inclusion criterion for the TIMES2 study was the presence of hypogonadism in men with T2DM and/or the MetS, so the cohort included both men with good as well as poor diabetic control. A benefit on HbA1c of testosterone therapy compared with placebo was observed after 9 months but not earlier (Jones et al. 2011).

Chronic cardiac failure is associated with a state of insulin resistance and also of testosterone deficiency. The cause of the reduced insulin sensitivity is related to the chronic inflammation with elevated levels, in particular, of TNF $\alpha$ and not obesity as this disease is associated with cachexia. TRT improves the insulin resistance but has no effect on body weight (Malkin et al. 2007a, Caminiti et al. 2009). The response to testosterone replacement of insulin sensitivity is in part dependent on the androgen receptor (AR). In the TIMES2 study, those subjects with more sensitive AR, as demonstrated by shorter CAG repeats in exon 1 of the gene encoding the AR, had a greater improvement of Homeostasis Model of Assessment - Insulin Resistance (HOMA-IR) in response to testosterone (Stanworth RD, Akhtar S, Channer \& Jones 2012, unpublished observations). There was no effect of transdermal TRT on hepatic insulin clearance in testosterone-deficient men (Basu et al. 2007).

Published by Bioscientifica Ltd. 
Several studies have shown that TRT in obese men reduces BMI and visceral fat mass (Rebuffé-Scrive et al. 1991, Mårin et al. 1992a,b, 1995, Saad et al. 2007, 2008, Agledahl et al. 2008). In the double-blinded placebo-controlled Moscow study, 184 men suffering from both MetS and hypogonadism showed significant decreases in weight, BMI and waist circumference following 30 weeks of testosterone replacement to the normal range (Kalinchenko et al. 2010). Other TRT studies have also reported improved body weight, BMI and waist circumference in men with MetS, T2DM and/or hypogonadism (Wang et al. 2000, Boyanov et al. 2003, Woodhouse et al. 2004, Kapoor et al. 2006, Allan et al. 2008, Svartberg et al. 2008, Jones et al. 2011).

\section{Testosterone effects on lipids}

Circulating lipid profiles are linked with obesity as central body fat is associated with altered lipoprotein ratios and composition, contributing to the risk of atherosclerosis (James et al. 1997). Such a disruption of this balance between so-called 'good' and 'bad' lipids is associated with increased cardiovascular risk. Indeed, elevated triglycerides and a reduced HDL-C level are central to the MetS and elevated total and LDL-cholesterol (LDL-C) levels are common in T2DM, although they are not individual components of the MetS. This highlights the need for careful management of hyperlipidaemia in the prevention of cardiovascular events (Jones 2010b).

Low levels of testosterone have been associated with an atherogenic lipoprotein profile, characterised by high LDL and triglyceride levels (Wu \& von Eckardstein 2003), and a negative correlation between serum levels of testosterone and total and LDL-C has been observed in cross-sectional studies (Barrett-Connor \& Khaw 1988, Barrett-Connor 1992, Haffner et al. 1993, Simon et al. 1997, Barud et al. 2002). Additionally, a positive correlation between serum testosterone and HDL has been reported in both healthy and diabetic men (Simon et al. 1997, Van Pottelbergh et al. 2003, Stanworth et al. 2011). Moreover, patients undergoing ADT demonstrate increased total cholesterol and LDL-C (Dockery et al. 2003, Nishiyama et al. 2005, Braga-Basaria et al. 2006, Yannucci et al. 2006), elevated triglycerides and reduced HDL-C (Haffner et al. 1993), or all these indicators of atherogenic lipid profiles (Haider et al. 2007) when compared with baseline or controls. In contrast to these studies, however, Khaw et al. (2007) reported that LDL levels were increased in patients in the upper quartile of endogenous testosterone levels compared with the lower quartile, yet a positive association between HDL and testosterone level was apparent. A few cross-sectional studies, however, have found no association between serum lipid measurements and endogenous testosterone (Kiel et al. 1989, Denti et al. 2000).

The majority of data from studies investigating TRT in hypogonadal and eugonadal men show some improvements in lipid and lipoprotein profiles. Indeed, metaanalysis of clinical trials in hypogonadal men report that significant reductions in total cholesterol and LDL-C are associated with intramuscular TRT (Whitsel et al. 2001, Isidori et al. 2005, Jones \& Saad 2009). Of particular interest, it has been reported that testosterone replacement reduces cholesterol and LDL-C in elderly men already treated with statins, indicating that TRT may be therapeutically beneficial beyond statin treatment alone (Jones \& Saad 2009). Heufelder et al. (2009) were one of the few authors to demonstrate a significant reduction in serum triglycerides and a significant increase in serum HDL-C levels following 12 months of TRT in hypogonadal men with T2DM. Similarly, over a 1-year period of testosterone replacement, HDL levels were reported to increase in men with MetS (Saad et al. 2007), and in hypogonadal men over a shorter time period (Zitzmann \& Nieschlag 2007). The majority of studies on the effect of testosterone on HDL-C, however, have generated contradictory results with either a decreases (Thompson et al. 1989, Bagatell et al. 1994) or no change (Zgliczynski et al. 1996, Uyanik et al. 1997, Boyanov et al. 2003, Malkin et al. 2004a, Kapoor et al. 2006). The reasons for the differences between the studies are unclear; however, it has been proposed that testosterone stimulation of reverse cholesterol transport may lead to increased consumption of HDL-C (Wu \& von Eckardstein 2003). A long-term TRT investigation may support this hypothesis by demonstrating that after an initial fall in their serum concentrations, HDL-C levels return to baseline levels after 12 months (Jones et al. 2011).

\section{Potential metabolic mechanisms of testosterone action}

The mechanisms linking testosterone with insulin resistance and T2DM are still not fully understood and there are few published papers that have investigated potential mechanisms by which testosterone increases insulin sensitivity and regulates glucose and lipid metabolism. The major insulin-responsive target tissues, such as skeletal muscle, liver and adipose tissue, inadequately respond to the physiologic effects of circulating insulin in

Published by Bioscientifica Ltd 
T2DM. Impaired insulin sensitivity in these three tissues is characterised by defects in insulin-stimulated glucose transport activity, in particular into skeletal muscle, impaired insulin-mediated inhibition of hepatic glucose production and stimulation of glycogen synthesis in liver, and a reduced ability of insulin to inhibit lipolysis in adipose tissue. In addition, as a consequence of dissociated fatty acid (FA) release from adipose tissue surplus to energy requirements in other organs, fat deposition in nonadipose tissue including skeletal muscle and liver occurs as a 'spillover' effect (Yu \& Ginsberg 2005). In turn, this lipid accumulation contributes to impaired insulin responsiveness and abnormalities in glucose control (Fig. 2). Indeed, fat in liver and muscle correlates more strongly with insulin sensitivity than abdominal fat in rats (Lim et al. 2008). A growing body of studies has pointed to the

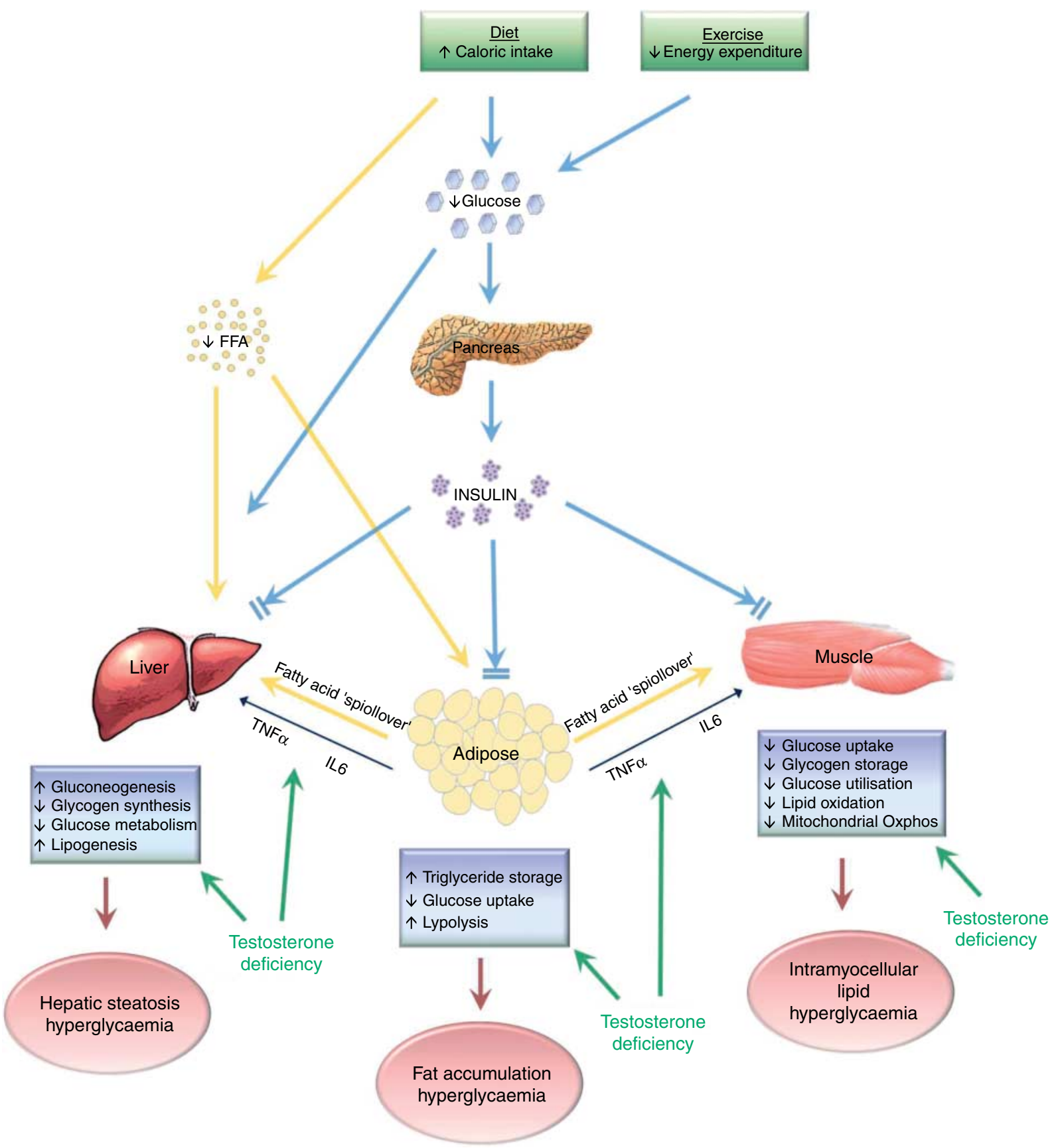


presence of heterogeneity regarding insulin resistance and insulin sensitivity among different tissues (Stumvoll et al. 2000); therefore, the mechanisms by which testosterone may impart beneficial actions on the development of T2DM and MetS are likely to be tissue dependent and involve multiple targets of lipid and carbohydrate metabolism (Table 1).

\section{Muscle}

Testosterone deficiency is associated with a decrease in lean body mass, and relative muscle mass is inversely associated with insulin resistance and pre-diabetes (Srikanthan \& Karlamangla 2011). As up to $70 \%$ of the body's insulin sensitivity is accounted for by muscle, low testosterone may lead to insulin resistance via anabolic and/or metabolic effects on muscle (Pitteloud et al. 2005b). Currently, however, little is known regarding the influence of testosterone on insulin action in skeletal muscle and the subsequent consequences on glucose metabolism and T2DM.

Glucose metabolism It has been long known that castration is followed by decreased muscle glycogen levels in rat perineal and levator ani muscles and that the administration of testosterone induces a considerable increase in glycogen content (Leonard 1952, Apostolakis et al. 1963, Bergamini et al. 1968). An equal increase in skeletal muscle glycogen synthesis is apparent in castrated male rats supplemented with testosterone, diminishing the elevated blood glucose levels seen in untreated controls (Ramamani et al. 1999). A testosterone-induced increase in glycogen synthase activity was implicated for the alteration in the rate of glycogen synthesis from blood glucose. Concurrently, testosterone administration returned the enhanced glycogen phosphorylase activity in castrated rats to a normal level, thus reducing glycogen breakdown and the subsequent rise in free glucose. By contrast, the rate of glycogenesis was shown to be depressed by testosterone in rat skeletal muscle with increased glycogen content postulated rather as a result of decreased glycogenolysis (Bergamini 1975). In perineal muscle, however, glycogenesis was increased in response to testosterone, suggesting differential mechanisms in different tissue locations.

Insulin-stimulated glucose uptake into muscle and adipose tissue is largely mediated by the Glut4 glucose transporter isoform. Under normal resting conditions, most of the Glut 4 molecules reside in membrane vesicles inside the cell. To increase glucose transport, GLUT4 translocates to the cell membrane in response to insulin via signalling through the insulin receptor, subsequent binding of insulin receptor substrate 1 (IRS1) and activation of intracellular signalling pathways (Bryant et al. 2002). Thus, several studies have demonstrated that diminished GLUT4 (SLC2A4) expression correlates with decreased insulin responsiveness, and defects at the level of the insulin receptor, IRS1 and GLUT4 expression have been observed in patients with T2DM (Pessin \& Saltiel 2000). In agreement with androgen action on glucose control, GLUT4 and IRS1 were up-regulated in cultured adipocytes and skeletal muscle cells following testosterone treatment at low dose and short-time incubations (Chen et al. 2006). Similarly, testosterone treatment increased IRS2 mRNA in cells isolated from male human skeletal muscle biopsies (Salehzadeh et al. 2011). Sato et al. (2008)

\section{Figure 2}

Obesity-induced insulin resistance. Chronic excessive dietary fat and carbohydrate intake coupled with a decrease in energy expenditure leads to a sustained rise in circulating free fatty acids (FFA) and blood glucose concentration. Excess FFA (yellow arrows) are incorporated into adipocyte triglyceride storage increasing visceral and subcutaneous fat mass. Adipose accumulation promotes the release of FFA into the circulation via lipolysis and these are taken up by muscle and liver in a 'spillover' effect. With accumulation of intramyocellular lipid, insulin-mediated skeletal muscle glucose uptake and utilisation is impaired along with decreased glycogen synthesis and lipid oxidation. As a result, excess glucose is diverted to the liver. In the liver, increased liver lipid also impairs the ability of insulin to regulate gluconeogenesis and activate glycogen synthesis. Hepatic lipogenesis further increases lipid content and can lead to hepatic steatosis. Impaired insulin action in the adipose tissue allows for increased lipolysis, which additionally promotes re-esterification of lipids in other tissues (such as liver and muscle) and further exacerbates insulin resistance. At the same time, adipose-derived inflammatory mediators contribute to the development of tissue insulin resistance (dark blue arrows). In particular, IL6 and TNF $\alpha$ inhibit the normal tyrosine phosphorylation of IRS 1 and downstream signalling in hepatic tissue reducing insulin sensitivity. Similarly, TNF $\alpha$ promotes insulin resistance in skeletal muscle via IRS1 degradation and inhibition of insulin signalling. Although IL 6 has been shown to exert some insulin sensitising effects in muscle, evidence also indicates a negative impact on insulin action and glucose homoeostasis by decreasing gene transcription of Irs1, Glut4 and Ppary as well as IRS1 activity and thus reducing insulin-stimulated glucose uptake (see Wei et al. (2007)). Hyperglycaemia ensues. Testosterone deficiency contributes to tissuespecific mechanisms involved in the development of insulin resistance in liver, adipose and muscle tissue and promotes inflammation (green arrows). TRT may potentially improve the negative consequences of tissue-specific insulin insensitivity and improve metabolic function. http://joe.endocrinology-journals.org DOI: 10.1530/JOE-12-0455
(C) 2013 Society for Endocrinology Printed in Great Britain
Published by Bioscientifica Ltd 
Table 1 Influence of testosterone on targets of lipid and glucose homoeostasis

\begin{tabular}{|c|c|}
\hline Testosterone action & Tissue \\
\hline $\begin{array}{l}\text { Glucose homoeostasis } \\
\uparrow \text { Glut4 }\end{array}$ & Muscle $e^{a, b, c, d}$, liver ${ }^{c}$ and adipose $e^{a, b, c}$ \\
\hline $\begin{array}{l}\uparrow \mathrm{IR} \\
\uparrow \mathrm{IRS1} \\
\uparrow \mathrm{IRS2} \\
\uparrow \text { Akt } \\
\uparrow \text { Protein kinase C } \\
\uparrow \text { Phosphofructokinase } \\
\uparrow \text { Hexokinase } \\
\uparrow \text { UQRCB }\end{array}$ & $\begin{array}{l}\text { Liver }^{\mathrm{e}, \mathrm{f}} \text { and larynx } \\
\text { Muscle }^{\mathrm{a}} \text {, adipose }^{\mathrm{a}} \text { and liver } \\
\text { Muscle }^{\mathrm{h}} \\
\text { Muscle }^{\mathrm{b}} \\
\text { Muscle }^{\mathrm{b}} \\
\text { Muscle }^{\mathrm{b}} \\
\text { Muscle }^{\mathrm{b}, \mathrm{d}, \mathrm{i}} \\
\text { Muscle }^{\mathrm{j}}\end{array}$ \\
\hline $\begin{array}{l}\uparrow \text { Glycogen synthase } \\
\downarrow \text { Glycogen phosphorylase } \\
\uparrow \text { G6PD }\end{array}$ & $\begin{array}{l}\text { Muscle } e^{k} \\
\text { Muscle }{ }^{k} \\
\text { Muscle } e^{1, m}\end{array}$ \\
\hline $\begin{array}{l}\text { Lipid homoeostasis } \\
\downarrow \text { ACS } \\
\downarrow \text { ACC } \\
\uparrow \text { ACC } \\
\leftrightarrow \text { ACAT1 } \\
\leftrightarrow \text { LDLr } \\
\uparrow \text { ABC1 } \\
\downarrow \text { FAS } \\
\leftrightarrow \text { FAS } \\
\uparrow \text { FAS } \\
\uparrow \text { HMG-CoA } \\
\uparrow \text { GPAT } \\
\downarrow \text { HSL } \\
\uparrow \beta-A d r e n e r g i c \text { receptor } \\
\downarrow \text { ATGL } \\
\downarrow \text { LPL } \\
\uparrow \text { ApoE } \\
\downarrow \text { RBP4 } \\
\downarrow \text { SCd1 } \\
\uparrow \text { SCD } 1 \\
\downarrow \text { C7AH } \\
\text { SR-1B } \\
\text { MTTP }\end{array}$ & 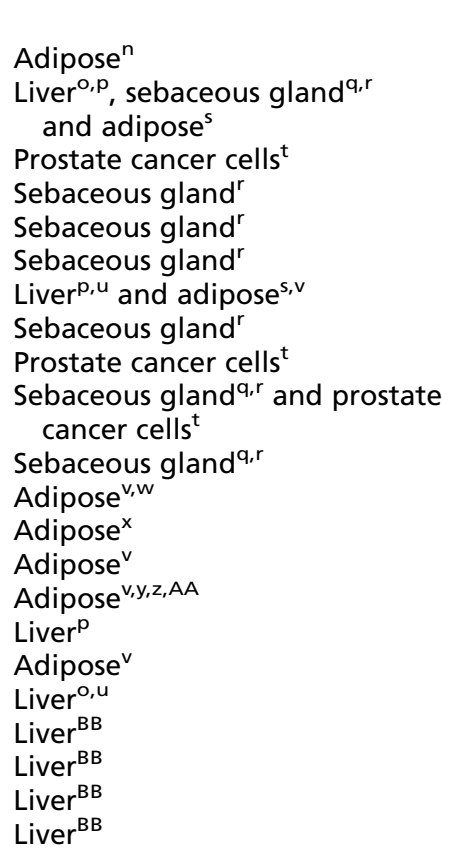 \\
\hline $\begin{array}{l}\text { Master regulators } \\
\uparrow \mathrm{LXR}\end{array}$ & Liver $^{p}$ \\
\hline$\downarrow$ PPAR $\gamma$ & Liver $^{\circ}$ and stem cells ${ }^{\complement C}$ \\
\hline $\begin{array}{l}\uparrow \text { SREBP-1C } \\
\uparrow \text { SREBP-1a } \\
\downarrow \text { SREBP-1C }\end{array}$ & $\begin{array}{l}\text { Sebaceous gland }{ }^{r} \text { and } \\
\text { prostate cancer cells }{ }^{\mathrm{DD}, \mathrm{EE}} \\
\text { Sebaceous gland }^{\mathrm{r}} \\
\text { Liver }^{\circ}\end{array}$ \\
\hline
\end{tabular}

\section{Target function}

Glucose transporter protein involved in cellular glucose uptake

Insulin signalling

Insulin signalling

Insulin signalling

Insulin receptor signalling pathway

Insulin receptor signalling pathway

Key regulatory enzyme in glycolysis

Key regulatory enzyme in glycolysis

Oxidative phosphorylation in mitochondrial respiration

Glycogenesis

Glycogen breakdown

Rate-limiting enzyme in the pentose phosphate pathway

De novo lipogenesis

FA synthesis

Conversion of cholesterol to cholesteryl esters

Receptor-mediated endocytosis of LDL

Cholesterol efflux

FA synthesis

Cholesterol synthesis

Cholesterol synthesis

Triglyceride breakdown

Noradrenaline-stimulated lipolysis

Lipolysis

Triglyceride uptake

Cholesterol efflux

Role in insulin resistance and lipid metabolism

Key enzyme in FA metabolism

Key enzyme in cholesterol conversion to bile acid

Selective uptake of cholesterol esters from HDL

Central role in lipoprotein assembly; $A p o B$ and VLDL secretion

Regulator of glucose and cholesterol metabolism, FA synthesis and inflammation

Whole-body energy homoeostasis adipogenesis and inflammation

Regulator of de novo lipogenesis, cholesterol homoeostasis and glucose homoeostasis

ABC1, ATP-binding cassette 1; ACAT1, acyl-CoA cholesterol acyl transferase-1; ACC, acetyl-CoA carboxylase; ACS, acyl-CoA synthetase; ApoE, apolipoprotein E; ATGL, adipose triglyceride lipase; C7AH, cholesterol $7 \alpha$-hydroxylase; FAS, fatty acid synthase, GLUT4, glucose transporter-4; GPAT, glycerol 3 phosphate acyl transferase, HMG-CoA, hydroxymethylglutaryl coenzyme A; HSL, hormone-sensitive lipase; IR, insulin receptor; IRS, insulin receptor substrate; LDLr, LDL receptor; LPL, lipoprotein lipase; LXR, liver X receptor; MTTP, microsomal triglyceride transfer protein; PPAR $\gamma$, peroxisome proliferator-activated receptor $\gamma$; RBP4, retinol-binding protein-4; Scd1, stearoyl-CoA desaturase 1; SR-1B, scavenger receptor class B member 1; SREBP-1C, sterol regulatory element binding protein 1C; UQRCB, ubiquinol cytochrome $c$ reductase-binding protein.

${ }^{a}$ Chen et al. (2006): 'b Sato et al. (2008); ' Muthusamy et al. (2009); ${ }^{d}$ McLaren et al. (2012): e Parthasarathy et al. (2009): ${ }^{f}$ Muthusamy et al. (2011): ${ }^{9}$ Sesti et al.

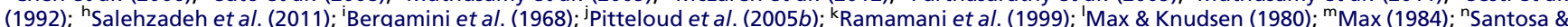

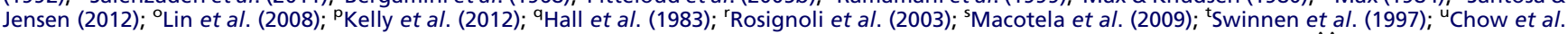
(2011); ${ }^{v}$ Mclnnes et al. (2012); ${ }^{w}$ Dicker et al. (2004); ${ }^{\times}$De Pergola (2000); ${ }^{{ }^{\prime}}$ Rebuffé-Scrive et al. (1991); ${ }^{\mathrm{z} M a ̊ r i n ~ e t ~ a l . ~(1995) ; ~}{ }^{A A}$ Ramirez et al. (1997); ${ }^{\mathrm{BB}}$ Movérare-Skrtic et al. (2006); “C ${ }^{\mathrm{CC}}$ Singh et al. (2002); ${ }^{\mathrm{D}}$ Huang et al. (2012); ${ }^{\mathrm{EE}}$ Heemers et al. (2001).

http://joe.endocrinology-journals.org DOI: 10.1530/JOE-12-0455 (c) 2013 Society for Endocrinology Printed in Great Britain
Published by Bioscientifica Ltd. 
demonstrated that GLUT4 expression and translocation was elevated following the addition of testosterone to cultured skeletal muscle cells of neonatal rats. Additionally, testosterone increased phosphorylation of Akt and protein kinase $\mathrm{C}$ (PKC), as key steps in the insulin receptor signalling pathways for regulation of GLUT4 translocation (Sato et al. 2008). These effects were blocked by a dihydrotestosterone (DHT) inhibitor, suggesting that local conversion of testosterone to DHT and activation of AR may be important for glucose uptake. Patients with Kennedy disease (a neuromuscular disorder) possess a genetic polymorphism with excess CAG repeats in exon 1 of the AR, leading to a condition associated with a relatively insensitive AR. In support of AR-dependent mechanisms, men with Kennedy disease have an increased risk of developing diabetes, thus providing further evidence of a link between impaired androgen status and diabetes (Stanworth et al. 2008, 2011, Zitzmann 2009b). Glut4 expression in the AR-deficient testicular feminised (Tfm) mouse, however, was shown to be up-regulated following testosterone replacement, suggesting some AR-independent actions (McLaren et al. 2012).

In addition to insulin signalling and glucose uptake, testosterone has been shown experimentally to influence key enzymes involved in glycolysis. Sato et al. (2008) reported that testosterone increased activity of phosphofructokinase and hexokinase in cultured rat skeletal muscle cells. In an early study, Bergamini et al. (1968) demonstrated a maximal $40 \%$ increase in hexokinase activity in castrated male rats $12 \mathrm{~h}$ after testosterone administration, with levels constantly above those of castrated rats over time. Preliminary work in the Tfm mouse, whereby affected animals present low endogenous testosterone levels and a non-functional AR, has also demonstrated that hexokinase- 2 expression was significantly reduced in skeletal muscle tissue of Tfm mice compared with wild-type (McLaren et al. 2012). Testosterone treatment did not significantly alter hexokinase-2 expression, suggesting an AR-dependent action.

In addition, glucose oxidation as an early step in glycolysis was increased in isolated sebaceous glands from testosterone-treated castrated male mice compared with castrated controls (Sansone et al. 1971). This increased oxidation, however, was considered to parallel increased glucose use in the pentose phosphate pathway for the generation of NADPH + and its subsequent utilisation in FA synthesis. Indeed, triglyceride, FA and wax ester were increased in the glands in a time-responsive manner rising from $24 \mathrm{~h}$ and reaching highest levels at 6 days posttestosterone injection. It is not clear whether castrate control tissue was investigated at all time points to eliminate the possibility of sebaceous gland lipid accumulation over time rather than a treatment effect. Glucose-6-phosphate dehydrogenase activity, the ratelimiting enzyme in the pentose phosphate pathway, was shown to be increased in rat levator ani muscle following administration of testosterone propionate, suggesting a potential action on $\mathrm{NADPH}+$ formation and possibly lipogenesis (Max \& Knudsen 1980, Max 1984).

Another potential mechanism for the beneficial effect of testosterone in diabetic men may be to increase the metabolic rate in skeletal muscle, promoting the acquisition of energy from adipose tissue and thus reducing fat mass. Pitteloud et al. (2005b) describes an inverse correlation between testosterone levels and adverse mitochondrial function, assessed by measuring maximal aerobic capacity $\left(\mathrm{VO}_{2} \mathrm{max}\right)$ in men with varying degrees of glucose control. In addition, the expression of genes involved in mitochondrial oxidative phosphorylation from skeletal muscle biopsies was related to testosterone levels, impaired glucose tolerance and the presence of T2DM. Of these genes, ubiquinol cytochrome $c$ reductasebinding protein (UQRCB) had the largest expression difference between normal and diabetic muscle and was correlated with testosterone and insulin resistance (Pitteloud et al. 2005b). UQRCB is involved in the activation of ubiquinol cytochrome $c$ reductase, which plays a critical role in oxidative phosphorylation.

Interestingly, orchidectomy of male Wistar rats and associated testosterone deficiency induced increased absorption of glucose from the intestine in a recent study (Olorunshola et al. 2012). A paradoxical significant decrease in cellular glucose uptake in the gut was observed when compared with sham-operated controls, suggesting a concurrent decrease in glucose utilisation by the gut. Subcutaneous testosterone propionate administration at a dose of $2.5 \mathrm{mg} / \mathrm{kg}$ body weight in castrated rats returned both gut absorption and utilisation of glucose to sham levels. This offers another alternate mechanism by which testosterone may contribute to the regulation of blood glucose levels.

Lipid metabolism Muscle tissue additionally has a role in lipid metabolism. Fat is oxidised in the liver and extra-hepatic tissue such as skeletal muscle and this component of lipid metabolism may be influenced by testosterone. Adverse effects on energy expenditure and fat oxidation were observed in elderly males suffering from prostate cancer and undergoing androgen deprivation (Reis et al. 2009). Decreased fat oxidation and increased

Published by Bioscientifica Ltd 
glucose oxidation was observed post-orchiectomy compared with pre-treatment. Likewise, testosterone deficiency induced by gonadal steroid suppression in healthy young men resulted in a significant decline in rates of lipid oxidation, with parallel changes in resting energy expenditure resulting in increased adiposity (Mauras et al. 1998). Furthermore, short-term (2 weeks) transdermal testosterone treatment stimulated wholebody fat oxidation and reduced the increased fat mass in testosterone-deficient men with hypopituitarism (Birzniece et al. 2009). Increased fat oxidation was not associated with an increase in resting energy expenditure or alterations in glucose oxidation leading the authors to postulate that a decrease in protein oxidation may be the source. Indeed, intramuscular TRT has been shown to reduce protein oxidation in hypogonadal men (Gibney et al. 2005). By contrast, orchidectomised mice treated with DHT resulted in obesity due to decreased fat oxidation and reduced energy expenditure while food consumption and locomotor activity remained unchanged (Movérare-Skrtic et al. 2006). The decrease in total body fat oxidation was not associated with a decrease in rate-limiting enzymes involved in $\beta$-oxidation in skeletal muscle or liver. The authors suggest that DHT may be acting indirectly on fat oxidation by reducing glucose oxidation. The disparity in these studies may be due to the differential influence of different hormones in different metabolic environments. The response to energy requirements by switching between lipid, glucose and protein oxidation in skeletal muscle is essential for metabolic homoeostasis, with impairment of this termed 'metabolic inflexibility' (Kelley \& Mandarino 2000). Frederiksen et al. (2012a) recently demonstrated that testosterone may influence components of metabolic flexibility as 6 months of transdermal testosterone treatment in aging men with low-normal bioavailable testosterone levels increased lipid oxidation and decreased glucose oxidation during the fasting state.

Decreased lipid oxidation coupled with diet-induced chronic FA elevation is linked to increased accumulation of myocellular lipid, in particular diacylglycerol and/or ceramide in myocytes (Itani et al. 2002, Stratford et al. 2004). In turn, triglyceride and lipid build-up in muscle impairs insulin signalling leading to decreased insulin sensitivity, demonstrating the link between myocellular lipid and insulin resistance. By potentially enhancing lipid oxidation in muscle, improving circulating lipid profiles and sensitising myocyte insulin signalling and glucose metabolism, testosterone may protect against the detrimental myocellular consequence of dysregulated lipid metabolism in T2DM, obesity and MetS, although further investigation is required.

\section{Liver}

Glucose metabolism The liver has a prominent role in the maintenance of glucose and lipid homoeostasis through the function of multiple metabolic pathways. In addition to insulin, experimental data indicate that many other hormones influence hepatic glucose control. In the Chang human adult liver cell line, insulin receptor mRNA expression was significantly increased following exposure to testosterone. This resulted in increased insulin binding, as measured by radio receptor assay and elevated glucose oxidation compared with basal response (Parthasarathy et al. 2009). Sesti et al. (1992) also reported that testosterone and DHT treatment of human larynx carcinoma cell line (HEp-2) significantly increased insulin receptor mRNA levels and insulin receptor number as well as enhancing insulin responsiveness through elevated glucose utilisation. Similarly, testosterone administration in orchidectomised adult male rats increased insulin receptor mRNA and protein expression in liver tissue and was associated with a normalisation of the castration-induced impairment of glucose oxidation (Muthusamy et al. 2011). Serine phosphorylation of IRS1, known to attenuate insulin signalling by inhibiting tyrosine phosphorylation (Aguirre et al. 2002), was elevated in castrated mice, with testosterone treatment significantly improving this effect even beyond control levels (Muthusamy et al. 2011).

Testosterone deprivation via castration of male rats led to decreased expression of Glut4 in liver tissue, as well as adipose and muscle (Muthusamy et al. 2009). GLUT4 translocation, measured by the ratio of cytosolic to membrane protein fractions, was also inhibited. These cellular mechanisms were accompanied by an elevation of blood glucose, reduced insulin levels and decreased glucose uptake in adipose and skeletal muscle tissue. Physiologically, replacing testosterone in these animals restored Glut4 expression and glucose uptake to wild-type levels. Oestrogen treatment had a limited effect on these parameters. The direct actions of testosterone were unclear and the authors indicate that the impairment of Glut4 expression may result from castration-induced deficiency in insulin. By contrast, within the promoter region of the human insulin receptor gene, two functional oestrogen response elements have been identified, suggesting that testosterone actions may be

Published by Bioscientifica Ltd. 
via aromatisation (García-Arencibia et al. 2005). Indeed, oestrogen was found to increase the expression of insulin receptors in insulin-resistant HepG2 human liver cell line (Xie et al. 2003).

Lipid metabolism Liver fat is correlated with all components of MetS, and obesity directly impacts on liver function. Visceral fat blood supply is cleared into the hepatic portal vein, in contrast to the peripheral fat, which is drained by the systemic circulation (Mårin \& Arver 1998). Consequently, the liver is exposed to products of adipocyte metabolism, such as free FA (FFA) and adipocytokines, in high concentrations and may induce metabolic disorders due to subsequent perturbation of liver metabolism. FFA decrease hepatic insulin binding and extraction, increase hepatic gluconeogenesis and increase hepatic insulin resistance. Ultimately, these effects lead to peripheral hyperinsulinaemia, systemic insulin resistance and hepatic steatosis. A reduction in adipocyte metabolism by testosterone would therefore reduce FFA production and, in turn, insulin resistance. The relationship between hepatic steatosis and serum testosterone concentrations has not yet received sufficient attention. Only one, albeit large-scale, population-based cross-sectional study reports an association between low serum testosterone concentrations and hepatic steatosis in men (Völzke et al. 2010). Two smaller studies report contrasting results in patients with hepatic steatosis as one reported low serum concentrations of testosterone and the other reported no significant differences in serum levels (Kley et al. 1975, Myking et al. 1987). Another study demonstrated through the generation of a hepatic AR knockout mouse model that a high-fat diet induced hepatic steatosis and insulin resistance in male but not in female mice (Lin et al. 2008). One of the contributing factors was hypothesised to be due to an increase in de novo lipid synthesis with loss of AR function, as hepatic expression of sterol regulatory element binding protein 1c (SREBP-1C), stearoyl-CoA desaturase 1 (SCD1), acetyl-CoA carboxylase (ACC (ACACA)) and proteasome proliferatoractivated receptor $\gamma$ (PPAR $\gamma$ (PPARG)), key enzymes in the regulation of FA synthesis, were up-regulated. Of interest, SCD1 is the rate-limiting enzyme of monounsaturated FA biosynthesis and increasing evidence implicates it as a novel control point in the pathogenesis of lipid-induced insulin resistance (Dobrzyn et al. 2010). Importantly, however, Lin et al. did not measure testosterone levels in high-fat diet-fed animals and thus could not determine whether increased hepatic steatosis was due to $A R$ function or an obesity-related testosterone decline. By contrast, hepatic Scd1 mRNA expression was increased following DHT treatment in orchidectomised obese mice compared with placebo-treated controls (Movérare-Skrtic et al. 2006). Significantly elevated $S c d 1$ expression also remained when compared to sham-operated controls, suggesting possible pharmacological effects of DHT administration.

Movérare-Skrtic et al. (2006) showed a modest increase in scavenger receptor class B member 1 (SR-1B) expression in the liver of castrated obese mice treated with DHT. Hepatic SR-1B is involved in selective uptake of cholesterol esters from circulating HDL facilitating reverse cholesterol transport. At the same time, microsomal triglyceride transfer protein was decreased by DHT, thus reducing apolipoprotein B-mediated very LDL (VLDL) secretion. Cholesterol $7 \alpha$-hydroxylase, a key enzyme in bile acid formation and therefore removal of cholesterol from the body, was decreased following DHT administration in this study, leading to hepatic lipid accumulation due to increased cholesterol uptake but decreased removal (Movérare-Skrtic et al. 2006). Contrariwise, AR-independent effects on hepatic steatosis and lipid metabolism have been demonstrated in the Tfm mouse (Kelly et al. 2012). A high-cholesterol diet induced significant hepatic lipid accumulation in Tfm mice compared to wild-type, and intramuscular testosterone replacement significantly abrogated this effect. An AR-independent action on de novo lipogenesis was considered as testosterone administration reduced the elevated expression of FA synthase (FAS) and ACC observed in the Tfm mouse in addition to increasing apolipoprotein $\mathrm{E}$ (apoE), an important protein in cholesterol transport/efflux. A concomitant increase in hepatic liver X receptor (LXR), as a master regulator of glucose and cholesterol metabolism and inflammation, was also described, suggesting that some of the beneficial actions of testosterone on hepatic lipid accumulation and metabolism may occur via a LXR effect that is independent of the AR (Kelly et al. 2012). In aromatase null (ArKO) male mice, hepatic transcript expression of Fas and $S c d 1$ was significantly elevated compared with wild-type males, but only Fas expression was lowered to wild-type level after ER $\alpha$ agonist treatment (Chow et al. 2011). This suggests that testosterone may confer some of its beneficial effects on hepatic lipid metabolism via conversion to $\mathrm{E}_{2}$ and subsequent activation of $\mathrm{ER} \alpha$.

\section{Adipose tissue}

Adipose tissue plays a major role in glucose homoeostasis and insulin sensitivity through the regulation of lipid and

Published by Bioscientifica Ltd 
glucose metabolism. Rather than obesity per se being related to testosterone levels in men, adiposity and particularly the location of adipose distribution appear to influence both androgen concentrations and cardiovascular risk. Specifically, a strong inverse correlation between body fat and testosterone level is evident (Kapoor et al. 2005), with hypogonadal men exhibiting a reduced lean body mass and an increased fat mass, abdominal or central obesity (Seidell et al. 1990, Haffner et al. 1993, Phillips 1993, Couillard et al. 2000). Central adiposity may not fully correlate with the degree of visceral fat volume; therefore, more accurate methods for assessing visceral fat volume may provide more detailed investigation. Using computed tomography (CT) scanning, Tsai et al. (2000) showed an inverse correlation between the total testosterone levels of 110 men and accumulation of visceral fat, but not other fat depots, after a 7.5-year follow-up. Similarly, other studies using CT and MRI scanning confirmed this inverse relationship of testosterone with visceral fat (Seidell et al. 1990, Couillard et al. 2000, Garaulet et al. 2000). In a population of young men aged 20-29 years, Nielsen et al. (2007) showed by dual-energy X-ray absorptiometry and MRI that the level of visceral adipose tissue was inversely correlated with bioavailable testosterone. By contrast, there was no change in visceral fat mass in aged men with low testosterone levels following 6 months of transdermal TRT, yet subcutaneous fat mass was significantly reduced in both the thigh and the abdominal areas when analysed by MRI (Frederiksen et al. 2012b). However, ADT of prostate cancer patients increased both visceral and subcutaneous abdominal fat in a 12-month prospective observational study (Hamilton et al. 2011).

Lipolysis, or the breakdown of lipids for energy usage, in adipose tissue is influenced by androgens and may be a mechanism by which testosterone affects fat storage and obesity. Catecholamines are the major lipolysis regulating hormones in man and regulate adipocyte lipolysis through activation of adenylate cyclase to produce cAMP. The PKA complex is activated by cAMP which, in turn, stimulates hormone-sensitive lipase (HSL) to accelerate the breakdown of triglycerides in the process of lipolysis (Arner 2005). An early study undertaken in rodents demonstrated that testosterone enhanced noradrenaline-stimulated lipolysis in isolated fat cells from normal male rats (Hansen et al. 1980). Testosterone may also increase lipolysis by increasing the number of $\beta$-adrenergic receptors (De Pergola 2000).

Evidence from the AR knockout (ARKO) mouse model indicates that deficiency of androgen action decreases lipolysis and is primarily responsible for the induction of obesity (Yanase et al. 2008). Moreover, castration was found to reduce basal lipolysis in male hamsters (Pecquery et al. 1988). However, testosterone treatment also led to a 50\% reduction in catecholamine-stimulated lipolysis in fully differentiated pre-adipocytes isolated from subcutaneous, but not visceral, human fat depots (Dicker et al. 2004). This reduction was matched by significantly decreased expression of HSL, as the final rate-limiting step for catecholamine-induced lipolysis. Taken together, these data suggest that there may be some regional differences in the action of testosterone on subcutaneous and visceral adipose function. Clinically, Abate et al. (2002) support this notion reporting that subcutaneous fat accumulation in the truncal area is highly predictive of low plasma concentrations of free testosterone rather than visceral adiposity. Dhindsa et al. (2007) also found a strong inverse relationship between subcutaneous fat mass and free and total testosterone in another study of men with T2DM. Furthermore, prostate cancer patients undergoing ADT present increased central adiposity and percentage body fat and decreased lean mass (Smith et al. 2001, 2002, 2006) with the change in body fat demonstrated to be mainly subcutaneous and not in visceral fat depots, which is atypical for the MetS (Faris \& Smith 2010). To the best of our knowledge, there are no mechanistic studies that address the differential response to testosterone in different adipose tissues.

Androgens have been shown to affect the expression of several key enzymes involved in lipogenesis. Using the hamster ear sebaceous gland model, DHT strongly induced the synthesis of triglycerides, squalene and cholesterol esters with increased expression of hydroxymethylglutaryl coenzyme A (HMG-CoA) reductase and synthase, ACC and glycerol 3 phosphate acyl transferase (GPAT) (Hall et al. 1983, Rosignoli et al. 2003). No effect was seen for the expression of $F A S$, acyl-CoA cholesterol acyl transferase-1 (ACAT1) and LDL receptor mRNA (Rosignoli et al. 2003). The mechanism of lipogenic gene up-regulation was considered to be via the SREBP pathway as DHT increased SREBF1 (both 1a and 1c isoforms) mRNA expression. SREBPs are considered master regulators of lipid homoeostasis, controlling the expression of a range of enzymes required for endogenous cholesterol, FA, triacylglycerol and phospholipid synthesis (Brown \& Goldstein 1999). Although DHT did not alter expression of SREBP cleavageactivating protein (SCAP), a chaperone protein responsible for SREBP activation, SCAP activity may still be a target for androgen action (Rosignoli et al. 2003). As this study only investigated the effects of DHT, any alternative AR-independent actions of testosterone may not have

Published by Bioscientifica Ltd. 
been explicated. In addition, sebaceous glands are actively lipogenic, functioning to produce lipid containing sebum for the lubrication and waterproofing of the skin and hair. Indeed, expression of ATP-binding cassette 1 (ABC1), involved in cholesterol efflux, was also elevated by DHT, indicating that the increased lipids may be secreted from sebaceous glands (Rosignoli et al. 2003). Therefore, androgen stimulation of lipogenesis in this tissue may not be applicable to the major tissues involved in the pathogenesis of T2DM and MetS, although these studies do indicate the potential for androgen modulation of lipogenic gene expression.

In prostate cancer cell lines, a similar increase in SCAP expression and SREBP activity following androgen treatment has been described (Heemers et al. 2001). Indeed, androgen treatment of LNCaP cells resulted in a three- to fourfold stimulation of the steady-state mRNA levels of FAS and up to tenfold increase in FAS activity (Swinnen et al. 1997). HMG-CoA synthase and reductase as well as ACC expression was also elevated in the presence of synthetic androgen (Swinnen et al. 1997) reflective of a marked accumulation of cholesteryl esters (Swinnen et al. 1996). Up-regulation of these lipogenic genes was again mediated via SREBP and SCAP, and supporting this notion, Heemers et al. (2004) identified an androgen response element located in intron 8 of the SCAP gene. These findings suggest that rather than influencing the expression of lipogenic enzymes individually, androgens may modulate the expression and/or activity of common transcription factors regulating their coordinate control (see Swinnen \& Verhoeven (1998)). Prostate cells display greatly enhanced AR expression and growth, and progression of prostate cancer cells is driven by the activation of AR and lipogenesis with SREBP-1 central to this interaction (Huang et al. 2012). Therefore, again this tissue is specific in its functioning and may not allow extrapolation of study findings to other tissues.

In addition, testosterone appears to inhibit lipid uptake potentially via affecting the expression of adipocyte lipoprotein lipase (LPL). LPL resides on the extracellular surface of adipocytes and hydrolyses circulating triglyceride-rich lipoproteins to FA, which are taken up into the adipocyte and then esterified back into triglycerides for storage (Eckel 1989). Owing to its important role in lipid uptake, the abnormal activity of this enzyme has been suggested as a potential contributing factor in the pathogenesis of obesity (Gruen et al. 1978). Ramirez et al. (1997) demonstrated that abdominal adipose tissue LPL activity in sedentary obese men at their usual weight was significantly inversely correlated with plasma levels of bioavailable testosterone. In middle-aged men, an oral testosterone preparation caused a significant decrease in abdominal LPL activity when administered either in a single large dose or following a smaller four times daily dose for 6 weeks (Rebuffé-Scrive et al. 1991). Nine-month testosterone treatment of hypogonadal men has been reported to produce a marked decrease in both LPL activity and triglyceride uptake in subcutaneous abdominal adipose tissue (Mårin et al. 1995). Following further investigation, the inhibition of lipid uptake after testosterone administration was more apparent in visceral than in abdominal subcutaneous adipose tissue (Mårin et al. 1996). The authors suggest that this testosterone-mediated intra-abdominal inhibition of triglyceride assimilation directs lipid to subcutaneous fat in men (Mårin et al. 1996). Thus, when testosterone is reduced, this promotes enhanced triglyceride storage in visceral depots.

Santosa \& Jensen (2012) have recently investigated the chronic effects of testosterone deficiency on adipose tissue FA storage. Men with chronic hypogonadism induced by at least 6 months of ADT for the prevention of prostate carcinoma reoccurrence were compared to eugonadal control men matched for age and body composition. Results of the study showed that hypogonadal men stored a greater proportion of both dietary FA and FFA in lower body subcutaneous fat than did eugonadal men and that this was associated with increased expression of acyl-CoA synthetase (ACS (ACSS2)) from femoral adipose biopsies. Indeed, increased ACS suggests a potential for an accumulation of intracellular acylated FA. Acylated FA are additionally considered to act as signalling molecules, modulating other enzymes involved in FA metabolism such as ACC, AMP-activated kinase-kinase, HMG-CoA reductase, carnitine palmitoyl transferase and HSL (Knudsen et al. 1999). Castration of male mice resulted in an increase in mRNA expression of $F a s$ and $A c c$ in subcutaneous adipocytes and a non-significant increase in these lipogenic enzymes in intra-abdominal/perigonadal adipocytes (Macotela et al. 2009). Increases in subcutaneous Glut4 and intraabdominal Glut1 (Slc2a1) were also observed, however, suggesting that while testosterone deficiency increased lipogenic capacity, it also increased insulin sensitivity.

Beneficial influence of testosterone on adipogenesis is also demonstrated in studies investigating the direct effects of testosterone on cultured stem cells. Singh et al. (2002) reported that the treatment of isolated mouse pluripotent stem cells with testosterone stimulated the development of cells of myocyte lineage rather than adipocytes and that testosterone deficiency promoted the development of

Published by Bioscientifica Ltd 
adipocytes over myocytes. Down-regulated expression of $\operatorname{PPAR} \gamma$, which controls adipogenic differentiation and lipid metabolism, was also reported at the mRNA and protein level. These effects on adipogenesis were blocked by the AR antagonist bicalutamide, suggesting AR-dependent mechanisms. Indeed, adipocytes are recognised to express ARs, the density of which is positively regulated by testosterone. More recently, however, Du et al. (2009) reported that a pre-inhibition of the AR did not influence the down-regulation of PPAR $\gamma$ activity by testosterone.

Testosterone influence on adipose glucose and lipid homoeostasis are shown to be directed, at least in part, via the AR. Male mice with a selective adipocyte AR knockdown (fARKO) displayed metabolic dysregulation with early insulin resistance/hyperinsulinaemia on normal chow diet and accelerated insulin deficiency, hyperglycaemia and visceral obesity on high-fat diet (McInnes et al. 2012). These effects were associated with altered expression of metabolic targets, although a degree of adipose depot specificity was apparent. Fas and adipose triglyceride lipase (ATGL) mRNA levels were elevated in subcutaneous adipose from fARKO mice compared with controls, but no difference was observed in perigonadal fat depots. Expression of HSL and LPL, however, was elevated in both subcutaneous and perigonadal adipose tissue of fARKO mice. Although Irs1 expression was not altered, IRS1 phosphorylation at the tyrosine residue as a measure of activation was significantly decreased in fARKO compared with wild-type mice, a mechanism potentially involving retinol-binding protein-4 (RBP4). Indeed, Rbp4 expression was selectively elevated in adipose tissue of fARKO mice (McInnes et al. 2012), supporting the hypothesis that elevated expression of Rbp4 may have an important role in lipid metabolism and insulin resistance (Graham et al. 2006, Ost et al. 2007). These AR-dependent mechanisms in adipose tissue may therefore contribute to glucose homoeostasis, and dysregulation of these pathways as a result of testosterone deficiency may contribute to the development of T2DM and MetS.

As mentioned previously, visceral fat is an active secretory tissue producing adipocytokines and other proinflammatory factors. In particular, proinflammatory adipocytokines IL1, IL6 and TNF $\alpha$ are increased in obesity with a downstream effect that stimulates liver production of CRP and other cytokine release (Schuster 2010). This chronic inflammation seen locally at the adipose tissue level also recruits monocytes that further contribute to the growing inflammatory activity. Overproduction of proinflammatory cytokines, other macrophage products and hormones by adipose tissue directly and indirectly induce insulin resistance (Kahn et al. 2006, Shoelson et al. 2006). In addition, adipokines are secreted into the circulation contributing to systemic and peripheral vascular inflammation and dysfunction associated with CVD (Guzik et al. 2006). As previously discussed, testosterone has several beneficial actions that decrease lipid deposition and therefore has the potential to reduce the release of adipocytokines by reducing fat tissue mass. Indeed, observational evidence suggests that IL1 $\beta$, IL6, TNF $\alpha$ and CRP are inversely associated with serum testosterone levels in patients (Yang et al. 2005, Maggio et al. 2006, Kapoor et al. 2007a, Nettleship et al. 2007) and TRT has been reported to significantly reduce these proinflammatory mediators (Malkin et al. 2004b, Kalinchenko et al. 2010). RBP4, secreted by the adipose tissue, induces insulin resistance by reducing phosphatidylinositol-3-OH kinase signalling in the muscle, increasing the expression of phosphoenolpyruvate carboxykinase in the liver and local actions to inhibit tyrosine phosphorylation of IRS1 in adipose, along with diminished adiponectin and PPAR $\alpha$ (PPARA) activity typical for obesity (Yang et al. 2005). In a mouse model of selective fat tissue AR knockout (fARKO), Rbp 4 mRNA expression was selectively increased in adipose tissue, along with an increased susceptibility to visceral obesity following high-fat diet feeding (McInnes et al. 2012). This suggests a role for $A R$ in the metabolic actions of testosterone on fat accumulation and adipose tissue inflammatory response. McInnes et al. (2012) additionally demonstrated direct down-regulation of Rbp4 expression in the adipose-differentiated 3T3-L1 cells following treatment with non-aromatisable androgen. Su et al. (2009), however, showed elevated secretion of IL6 and MCP-1 in 3T3-L1 cells treated with testosterone, a mechanism that was dependent on NF- $\mathrm{BB}$ signalling.

Adiponectin and leptin are also two important adipokines that have been linked to T2DM and obesity. Unlike other adipose tissue-derived peptides that are elevated in obesity, adiponectin levels are decreased in obese individuals with insulin resistance, and higher levels of adiponectin are associated with lower risk of T2DM in older men and women (Krakoff et al. 2003, Spranger et al. 2003). Leptin levels are high in obese individuals and it has been suggested that resistance to leptin is one of the contributing factors to obesity and testosterone deficiency, as noted earlier in the hypogonadal-obesityadipocytokine hypothesis (Jones 2007). Kapoor et al. (2007b) demonstrated that both leptin and adiponectin are reduced following biweekly testosterone propionate treatment for 3 months. Similarly, TRT was shown to lower serum adiponectin (Lanfranco et al. 2004, Page et al.

Published by Bioscientifica Ltd. 
2005). These interventional studies, however, were shortterm and may reflect the reduction in total fat mass. Indeed, the reduction in these adipokines was correlated with a concomitant decrease in waist circumference (Kapoor et al. 2007b). The long-term effect of testosterone on adiponectin and leptin and the direct effects on adipocytokines remain unknown.

Consequently, testosterone treatment may have beneficial effects on preventing the pathogenesis of obesity by inhibiting adipogenesis, decreasing triglyceride uptake and storage, increasing lipolysis, influencing lipoprotein content and function and may directly reduce fat mass and increase muscle mass. This may, in turn, have a direct effect on circulating FA, the secretion of adipocytokines and subsequent insulin resistance. Some of these biochemical effects on lipid metabolism may be dependent on the location of the adipose depot and/or the tissue or cell type investigated. It is also worth noting that although the majority of studies report AR-dependent mechanisms, AR-independent effects in adipose tissue should not be discounted.

\section{Conclusions}

The high prevalence of clinical hypogonadism in men with T2DM and/or MetS has been shown in growing amounts of cross-sectional and epidemiological studies, and testosterone deficiency itself is a risk factor for the subsequent development of MetS and T2DM. Therefore, a bidirectional relationship between low testosterone with obesity and MetS is apparent. In parallel, the development of insulin resistance is multifaceted and involves multiple organs including liver, muscle and adipose tissue, which points to a heterogeneity among underlying mechanisms that could affect intervention strategies. This highlights the importance of taking multiple tissues into account and thus focussing on a systems biology approach. Early interventional studies suggest that TRT in hypogonadal men with T2DM and/or MetS has beneficial effects on lipids, adiposity and parameters of insulin sensitivity and glucose control. These effects of testosterone may be both acute and long-term in liver, adipose and muscle tissue with a rapid improvement in insulin sensitivity that occurs within a few days to few weeks of treatment and before loss of fat mass becomes evident and a prolonged effect associated with significant reduction of total and visceral body fat (Aversa et al. 2010b). The potential benefits of testosterone treatment must, of course, be balanced against its long-term risks. Large randomised, placebo-controlled clinical trials are therefore necessary to determine whether men with low levels of androgens can safely ingest long-term TRT and ultimately whether androgen replacement will reduce CVD risk in hypogonadal men over time.

Evidence that whole-body insulin sensitivity is reduced in testosterone deficiency and increases with testosterone replacement supports a key role of this hormone in glucose and lipid metabolism. These actions of testosterone are substantiated by demonstration of reported effects on fundamental and major biochemical regulators of glucose and lipid metabolism involved in insulin function. Furthermore, the different effects of testosterone in the major tissues involved in insulin sensitivity are consistent with the expected action of testosterone as an anabolic hormone. These underlying biochemical mechanisms of testosterone's potential therapeutic benefit remain unclear and require further and fuller investigation to understand the tissue-specific actions of testosterone and the influence of AR-dependent and -independent pathways in metabolic regulation.

\section{Declaration of interest}

The authors declare that there is no conflict of interest that could be perceived as prejudicing the impartiality of the review reported.

\section{Funding}

$\mathrm{T} \mathrm{H} \mathrm{J} \mathrm{is} \mathrm{a} \mathrm{consultant} \mathrm{for} \mathrm{ProStrakan} \mathrm{(Galashiels,} \mathrm{UK),} \mathrm{has} \mathrm{received} \mathrm{research}$ grants from Bayer HealthCare and received honoraria for educational lectures and advisory boards for Bayer HealthCare, Lilly, Merck and ProStrakan.

\section{References}

Abate N, Haffner SM, Garg A, Peshock RM \& Grundy SM 2002 Sex steroid hormones, upper body obesity, and insulin resistance. Journal of Clinical Endocrinology and Metabolism 87 4522-4527. (doi:10.1210/jc.2002-020567)

Agledahl I, Hansen JB \& Svartberg J 2008 Impact of testosterone treatment on postprandial triglyceride metabolism in elderly men with subnormal testosterone levels. Scandinavian Journal of Clinical and Laboratory Investigation 68 641-648. (doi:10.1080/00365510801999068)

Aguirre V, Werner ED, Giraud J, Lee YH, Shoelson SE \& White MF 2002 Phosphorylation of Ser307 in insulin receptor substrate-1 blocks interactions with the insulin receptor and inhibits insulin action. Journal of Biological Chemistry 277 1531-1537. (doi:10.1074/ jbc.M101521200)

Allan CA, Strauss BJ, Burger HG, Forbes EA \& McLachlan RI 2008 Testosterone therapy prevents gain in visceral adipose tissue and loss of skeletal muscle in nonobese aging men. Journal of Clinical Endocrinology and Metabolism 93 139-146. (doi:10.1210/jc.2007-1291)

Apostolakis M, Matzelt D \& Voigt KD 1963 The effect of testosterone propionate on glycolytic and transamination enzyme activities in the liver, biceps muscle and levator ani muscle in rats. Biochemische Zeitschrift 337 414-424.

Araujo AB, Dixon JM, Suarez EA, Murad MH, Guey LT \& Wittert GA 2011 Clinical review: endogenous testosterone and mortality in men: a 
systematic review and meta-analysis. Journal of Clinical Endocrinology and Metabolism 96 3007-3019. (doi:10.1210/jc.2011-1137)

Arner P 2005 Human fat cell lipolysis: biochemistry, regulation and clinical role. Best Practice \& Research. Clinical Endocrinology \& Metabolism 19 471-482. (doi:10.1016/j.beem.2005.07.004)

Aversa A, Bruzziches R, Francomano D, Spera G \& Lenzi A $2010 b$ Efficacy and safety of two different testosterone undecanoate formulations in hypogonadal men with metabolic syndrome. Journal of Endocrinological Investigation 33 776-783.

Bagatell CJ, Heiman JR, Matsumoto AM, Rivier JE \& Bremner WJ 1994 Metabolic and behavioral effects of high-dose, exogenous testosterone in healthy men. Journal of Clinical Endocrinology and Metabolism 79 561-567. (doi:10.1210/jc.79.2.561)

Barrett-Connor E 1992 Lower endogenous androgen levels and dyslipidemia in men with non-insulin-dependent diabetes mellitus. Annals of Internal Medicine 117 807-811.

Barrett-Connor E \& Khaw KT 1988 Endogenous sex hormones and cardiovascular disease in men. A prospective population-based study. Circulation 78 539-545. (doi:10.1161/01.CIR.78.3.539)

Barud W, Palusiński R, Bełtowski J \& Wójcicka G 2002 Inverse relationship between total testosterone and anti-oxidized low density lipoprotein antibody levels in ageing males. Atherosclerosis 164 283-288. (doi:10.1016/S0021-9150(02)00069-2)

Basu R, Dalla Man C, Campioni M, Basu A, Nair KS, Jensen MD, Khosla S, Klee G, Toffolo G, Cobelli C et al. 2007 Effect of 2 years of testosterone replacement on insulin secretion, insulin action, glucose effectiveness, hepatic insulin clearance, and postprandial glucose turnover in elderly men. Diabetes Care 30 1972-1978. (doi:10.2337/dc07-0359)

Bergamini E 1975 Different mechanisms in testosterone action on glycogen metabolism in rat perineal and skeletal muscles. Endocrinology 96 77-84. (doi:10.1210/endo-96-1-77)

Bergamini E, Bombara G \& Pellegrino C 1968 The effect of testosterone on glycogen metabolism in rat levator ani muscle. Biochimica et Biophysica Acta 177 220-234. (doi:10.1016/0304-4165(69)90131-7)

Birzniece V, Meinhardt UJ, Handelsman DJ \& Ho KK 2009 Testosterone stimulates extra-hepatic but not hepatic fat oxidation (Fox): comparison of oral and transdermal testosterone administration in hypopituitary men. Clinical Endocrinology 71 715-721. (doi:10.1111/j.1365-2265. 2009.03524.x)

Boyanov M, Boneva Z \& Christov V 2003 Testosterone supplementation in men with type 2 diabetes, visceral obesity and partial androgen deficiency. Aging Male 6 1-7.

Braga-Basaria M, Muller DC, Carducci MA, Dobs AS \& Basaria S 2006 Lipoprotein profile in men with prostate cancer undergoing androgen deprivation therapy. International Journal of Impotence Research $\mathbf{1 8}$ 494-498. (doi:10.1038/sj.ijir.3901471)

Brand JS, van der Tweel I, Grobbee DE, Emmelot-Vonk MH \& van der Schouw YT 2010 Testosterone, sex hormone-binding globulin and the metabolic syndrome: a systematic review and meta-analysis of observational studies. International Journal of Epidemiology 40 189-207. (doi:10.1093/ije/dyq158)

Brown MS \& Goldstein JL 1999 A proteolytic pathway that controls the cholesterol content of membranes, cells, and blood. PNAS 96 11041-11048. (doi:10.1073/pnas.96.20.11041)

Bryant NJ, Govers R \& James DE 2002 Regulated transport of the glucose transporter GLUT4. Nature Reviews. Molecular Cell Biology 3 267-277. (doi:10.1038/nrm782)

Caminiti G, Volterrani M, Iellamo F, Marazzi G, Massaro R, Miceli M, Mammi C, Piepoli M, Fini M \& Rosano GM 2009 Effect of long-acting testosterone treatment on functional exercise capacity, skeletal muscle performance, insulin resistance, and baroreflex sensitivity in elderly patients with chronic heart failure a double-blind, placebo-controlled, randomized study. Journal of the American College of Cardiology $\mathbf{5 4}$ 919-927. (doi:10.1016/j.jacc.2009.04.078)
Chen X, Li X, Huang HY, Li X \& Lin JF 2006 Effects of testosterone on insulin receptor substrate- 1 and glucose transporter 4 expression in cells sensitive to insulin. Zhonghua Yi Xue Za Zhi 86 1474-1477.

Chow JD, Jones ME, Prelle K, Simpson ER \& Boon WC 2011 A selective estrogen receptor $\alpha$ agonist ameliorates hepatic steatosis in the male aromatase knockout mouse. Journal of Endocrinology 210 323-334. (doi:10.1530/JOE-10-0462)

Cohen P 1999 The hypogonadal-obesity cycle. Medical Hypotheses 52 49-51. (doi:10.1054/mehy.1997.0624)

Corona G, Mannucci E, Schulman C, Petrone L, Mansani R, Cilotti A, Balercia G, Chiarini V, Forti G \& Maggi M 2006 Psychobiologic correlates of the metabolic syndrome and associated sexual dysfunction. European Urology 50 595-604. (doi:10.1016/j.eururo. 2006.02.053)

Corona G, Mannucci E, Forti G \& Maggi M 2009 Hypogonadism, ED, metabolic syndrome and obesity: a pathological link supporting cardiovascular diseases. International Journal of Andrology 32 587-598. (doi:10.1111/j.1365-2605.2008.00951.x)

Corona G, Monami M, Rastrelli G, Aversa A, Tishova Y, Saad F, Lenzi A, Forti G, Mannucci E \& Maggi M 2011 Testosterone and metabolic syndrome: a meta-analysis study. Journal of Sexual Medicine 8 272-283. (doi:10.1111/j.1743-6109.2010.01991.x)

Couillard C, Gagnon J, Bergeron J, Leon AS, Rao DC, Skinner JS, Wilmore JH, Després JP \& Bouchard C 2000 Contribution of body fatness and adipose tissue distribution to the age variation in plasma steroid hormone concentrations in men: the HERITAGE Family Study. Journal of Clinical Endocrinology and Metabolism 85 1026-1031. (doi:10.1210/jc.85.3.1026)

Denti L, Pasolini G, Sanfelici L, Benedetti R, Cecchetti A, Ceda GP, Ablondi F \& Valenti G 2000 Aging-related decline of gonadal function in healthy men: correlation with body composition and lipoproteins. Journal of the American Geriatrics Society 48 51-58.

De Pergola G 2000 The adipose tissue metabolism: role of testosterone and dehydroepiandrosterone. International Journal of Obesity and Related Metabolic Disorders 24(Suppl 2) S59-S63. (doi:10.1038/sj.ijo.0801280)

Derweesh IH, Diblasio CJ, Kincade MC, Malcolm JB, Lamar KD, Patterson AL, Kitabchi AE \& Wake RW 2007 Risk of new-onset diabetes mellitus and worsening glycaemic variables for established diabetes in men undergoing androgen-deprivation therapy for prostate cancer. BJU International 100 1060-1065.

Dhindsa S, Prabhakar S, Sethi M, Bandyopadhyay A, Chaudhuri A \& Dandona P 2004 Frequent occurrence of hypogonadotropic hypogonadism in type 2 diabetes. Journal of Clinical Endocrinology and Metabolism 89 5462-5468. (doi:10.1210/jc.2004-0804)

Dhindsa S, Bhatia V, Dhindsa G, Chaudhuri A, Gollapudi GM \& Dandona P 2007 The effects of hypogonadism on body composition and bone mineral density in type 2 diabetic patients. Diabetes Care 30 1860-1861. (doi:10.2337/dc07-0337)

Diaz-Arjonilla M, Schwarcz M, Swerdloff RS \& Wang C 2009 Obesity, low testosterone levels and erectile dysfunction. International Journal of Impotence Research 21 89-98. (doi:10.1038/ijir.2008.42)

Dicker A, Rydén M, Näslund E, Muehlen IE, Wirén M, Lafontan M \& Arner P 2004 Effect of testosterone on lipolysis in human preadipocytes from different fat depots. Diabetologia $47420-428$. (doi:10.1007/s00125-003-1324-0)

Ding EL, Song Y, Malik VS \& Liu S 2006 Sex differences of endogenous sex hormones and risk of type 2 diabetes: a systematic review and metaanalysis. Journal of the American Medical Association 295 1288-1299. (doi:10.1001/jama.295.11.1288)

Dobrzyn P, Jazurek M \& Dobrzyn A 2010 Stearoyl-CoA desaturase and insulin signaling - what is the molecular switch? Biochimica et Biophysica Acta 1797 1189-1194. (doi:10.1016/j.bbabio.2010.02.007)

Dockery F, Bulpitt CJ, Agarwal S, Donaldson M \& Rajkumar C 2003 Testosterone suppression in men with prostate cancer leads to an increase in arterial stiffness and hyperinsulinaemia. Clinical Science $\mathbf{1 0 4}$ 195-201. (doi:10.1042/CS20020209) 
Du J, Zhang L \& Wang Z 2009 Testosterone inhibits the activity of peroxisome proliferator-activated receptor $\gamma$ in a transcriptional transaction assay. Die Pharmazie 64 692-693.

Eckel RH 1989 Lipoprotein lipase. A multifunctional enzyme relevant to common metabolic diseases. New England Journal of Medicine $\mathbf{3 2 0}$ 1060-1068. (doi:10.1056/NEJM198904203201607)

Faris JE \& Smith MR 2010 Metabolic sequelae associated with androgen deprivation therapy for prostate cancer. Current Opinion in Endocrinology, Diabetes, and Obesity 17 240-246. (doi:10.1097/MED. Ob013e3283391fd1)

Finn PD, Cunningham MJ, Pau KY, Spies HG, Clifton DK \& Steiner RA 1998 The stimulatory effect of leptin on the neuroendocrine reproductive axis of the monkey. Endocrinology 139 4652-4662. (doi:10.1210/ en.139.11.4652)

Frederiksen L, Højlund K, Hougaard DM, Brixen K \& Andersen M 2012a Testosterone therapy increased muscle mass and lipid oxidation in aging men. Age 34 145-156. (doi:10.1007/s11357-011-9213-9)

Frederiksen L, Højlund K, Hougaard DM, Mosbech TH, Larsen R, Flyvbjerg A, Frystyk J, Brixen K \& Andersen M $2012 b$ Testosterone therapy decreases subcutaneous fat and adiponectin in aging men. European Journal of Endocrinology 166 469-476. (doi:10.1530/EJE-11-0565)

Garaulet M, Pérex-Llamas F, Fuente T, Zamora S \& Tebar FJ 2000 Anthropometric, computed tomography and fat cell data in an obese population: relationship with insulin, leptin, tumor necrosis factor- $\alpha$, sex hormone-binding globulin and sex hormones. European Journal of Endocrinology 143 657-666. (doi:10.1530/eje.0.1430657)

García-Arencibia M, Dávila N, Campión J, Carmen Carranza M \& Calle C 2005 Identification of two functional estrogen response elements complexed with AP-1-like sites in the human insulin receptor gene promoter. Journal of Steroid Biochemistry and Molecular Biology 94 1-14. (doi:10.1016/j.jsbmb.2004.12.020)

George JT, Millar RP \& Anderson RA 2010 Hypothesis: kisspeptin mediates male hypogonadism in obesity and type 2 diabetes. Neuroendocrinology 91 302-307. (doi:10.1159/000299767)

Gibney J, Wolthers T, Johannsson G, Umpleby AM \& Ho KK 2005 Growth hormone and testosterone interact positively to enhance protein and energy metabolism in hypopituitary men. American Journal of Physiology. Endocrinology and Metabolism 289 E266-E271. (doi:10.1152/ ajpendo.00483.2004)

Graham TE, Yang Q, Blüher M, Hammarstedt A, Ciaraldi TP, Henry RR, Wason CJ, Oberbach A, Jansson PA, Smith U et al. 2006 Retinol-binding protein 4 and insulin resistance in lean, obese, and diabetic subjects. New England Journal of Medicine 354 2552-2563. (doi:10.1056/ NEJMoa054862)

Grossmann M, Gianatti EJ \& Zajac JD 2010 Testosterone and type 2 diabetes. Current Opinion in Endocrinology, Diabetes, and Obesity 17 247-256. (doi:10.1097/MED.0b013e32833919cf)

Gruen R, Hietanen E \& Greenwood MR 1978 Increased adipose tissue lipoprotein lipase activity during the development of the genetically obese rat (fa/fa). Metabolism 12(Suppl 2) 1955-1966. (doi:10.1016/ S0026-0495(78)80012-2)

Guzik TJ, Mangalat D \& Korbut R 2006 Adipocytokines: novel link between inflammation and vascular function? Journal of Physiology and Pharmacology 57 505-528.

Haffner S, Mykkanen L, Valdez R \& Katz M 1993 Relationship of sex hormones to lipids and lipoproteins in non-diabetic men. Journal of Clinical Endocrinology and Metabolism 77 1610-1615. (doi:10.1210/ jc.77.6.1610)

Haffner SM, Shaten J, Stern MP, Smith GD \& Kuller L 1996 Low levels of sex hormone binding globulin and testosterone predict the development of non insulin dependent diabetes mellitus in men. American Journal of Epidemiology 143 889-897. (doi:10.1093/oxfordjournals.aje.a008832)

Haider A, Yassin A, Saad F \& Shabsigh R 2007 Effect of androgen deprivation on glycaemic control and on cardiovascular risk factors in men with advanced prostate cancer with diabetes. Aging Male 10 189-196. (doi:10.1080/13685530701653538)
Hall DW, Van den Hoven WE, Noordzij-Kamermans NJ \& Jaitly KD 1983 Hormonal control of hamster ear sebaceous gland lipogenesis. Archives of Dermatological Research 275 1-7. (doi:10.1007/BF00516546)

Hamilton EJ, Gianatti E, Strauss BJ, Wentworth J, Lim-Joon D, Bolton D, Zajac JD \& Grossmann M 2011 Increase in visceral and subcutaneous abdominal fat in men with prostate cancer treated with androgen deprivation therapy. Clinical Endocrinology 74 377-383. (doi:10.1111/ j.1365-2265.2010.03942.x)

Hansen FM, Fahmy N \& Nielsen JH 1980 The influence of sexual hormones on lipogenesis and lipolysis in rat fat cells. Acta Endocrinologica 95 566-570.

Haring R, Völzke H, Felix SB, Schipf S, Dorr M, Rosskopf D, Nauck M, Schofl C \& Wallaschofski H 2009 Prediction of metabolic syndrome by low serum testosterone levels in men. Results from the study of health in Pomerania. Diabetes Care 58 2027-2031. (doi:10.2337/db09-0031)

Hayes FJ, Seminara SB, Decruz S, Boepple PA \& Crowley WF Jr 2000 Aromatase inhibition in the human male reveals a hypothalamic site of estrogen feedback. Journal of Clinical Endocrinology and Metabolism $\mathbf{8 5}$ 3027-3035. (doi:10.1210/jc.85.9.3027)

Hayes FJ, DeCruz S, Seminara SB, Boepple PA \& Crowley WF Jr 2001 Differential regulation of gonadotropin secretion by testosterone in the human male: absence of a negative feedback effect of testosterone on follicle-stimulating hormone secretion. Journal of Clinical Endocrinology and Metabolism 86 53-58. (doi:10.1210/jc.86.1.53)

Heemers H, Maes B, Foufelle F, Heyns W, Verhoeven G \& Swinnen JV 2001 Androgens stimulate lipogenic gene expression in prostate cancer cells by activation of the sterol regulatory element-binding protein cleavage activating protein/sterol regulatory element-binding protein pathway. Molecular Endocrinology 15 1817-1828. (doi:10.1210/me.15.10.1817)

Heemers H, Verrijdt G, Organe S, Claessens F, Heyns W, Verhoeven G \& Swinnen JV 2004 Identification of an androgen response element in intron 8 of the sterol regulatory element-binding protein cleavageactivating protein gene allowing direct regulation by the androgen receptor. Journal of Biological Chemistry 279 30880-30887. (doi:10.1074/jbc.M401615200)

Heufelder AE, Saad F, Bunck MC \& Gooren L 2009 Fifty-two-week treatment with diet and exercise plus transdermal testosterone reverses the metabolic syndrome and improves glycemic control in men with newly diagnosed type 2 diabetes and subnormal plasma testosterone. Journal of Andrology 30 726-733. (doi:10.2164/jandrol.108.007005)

Huang WC, Li X, Liu J, Lin J \& Chung LW 2012 Activation of androgen receptor, lipogenesis, and oxidative stress converged by SREBP-1 is responsible for regulating growth and progression of prostate cancer cells. Molecular Cancer Research 10 133-142. (doi:10.1158/1541-7786. MCR-11-0206)

Isidori AM, Caprio M, Stroll F, Moretti C, Frajese G, Isidori A \& Fabbri A 1999 Leptin and androgens in male obesity: evidence for leptin contribution to reduced androgen levels. Journal of Clinical Endocrinology and Metabolism 84 3673-3680. (doi:10.1210/jc.84.10.3673)

Isidori AM, Giannetta E, Greco EA, Gianfrilli D, Bonifacio V, Isidori A, Lenzi A \& Fabbri A 2005 Effects of testosterone on body composition, bone metabolism and serum lipid profile in middle-aged men: a metaanalysis. Clinical Endocrinology 63 280-293. (doi:10.1111/j.1365-2265. 2005.02339.x)

Itani SI, Ruderman NB, Schmieder F \& Boden G 2002 Lipid-induced insulin resistance in human muscle is associated with changes in diacylglycerol, protein kinase C, and IкB- $\alpha$. Diabetes 51 2005-2011. (doi:10.2337/diabetes.51.7.2005)

James RW, Brulhart-Meynet MC, Lehmann T \& Golay A 1997 Lipoprotein distribution and composition in obesity: their association with central adiposity. International Journal of Obesity and Related Metabolic Disorders 21 1115-1120. (doi:10.1038/sj.ijo.0800524)

Jones TH 2007 Testosterone associations with erectile dysfunction, diabetes and the metabolic syndrome. European Urology Supplements 6 847-857. (doi:10.1016/j.eursup.2007.07.002) 
Jones TH $2010 a$ Testosterone deficiency: a risk factor for cardiovascular disease? Trends in Endocrinology and Metabolism 21 496-503. (doi:10.1016/j.tem.2010.03.002)

Jones TH $2010 b$ Effects of testosterone on type 2 diabetes and components of the metabolic syndrome. Journal of Diabetes 2 146-156. (doi:10.1111/ j.1753-0407.2010.00085.x)

Jones TH 2011 Cardiovascular risk during androgen deprivation therapy for prostate cancer. BMJ 342 d3105. (doi:10.1136/bmj.d3105)

Jones TH \& Saad F 2009 The effects of testosterone on risk factors for and the mediators of, the atherosclerotic process. Atherosclerosis $\mathbf{2 0 7}$ 318-327. (doi:10.1016/j.atherosclerosis.2009.04.016)

Jones TH, Arver S, Behre HM, Buvat J, Meuleman E, Moncada I, Morales AM, Volterrani M, Yellowlees A, Howell JD et al. 2011 Testosterone replacement in hypogonadal men with type 2 diabetes and/or metabolic syndrome (the TIMES2 study). Diabetes Care 34 828-837. (doi:10.2337/ dc10-1233)

Kalinchenko SY, Tishova YA, Mskhalaya GJ, Gooren LJ, Giltay EJ \& Saad F 2010 Effects of testosterone supplementation on markers of the metabolic syndrome and inflammation in hypogonadal men with the metabolic syndrome: the double-blinded placebo-controlled Moscow study. Clinical Endocrinology 73 602-612. (doi:10.1111/j.1365-2265. 2010.03845.x)

Kapoor D, Malkin CJ, Channer KS \& Jones TH 2005 Androgens, insulin resistance and vascular disease in men. Clinical Endocrinology 63 239-250. (doi:10.1111/j.1365-2265.2005.02299.x)

Kapoor D, Goodwin E, Channer KS \& Jones TH 2006 Testosterone replacement therapy improves insulin resistance, glycaemic control, visceral adiposity and hypercholesterolaemia in hypogonadal men with type 2 diabetes. European Journal of Endocrinology 154 899-906. (doi:10.1530/eje.1.02166)

Kapoor D, Aldred H, Clark S, Channer KS \& Jones TH 2007a Clinical and biochemical assessment of hypogonadism in men with type 2 diabetes: correlations with bioavailable testosterone and visceral adiposity. Diabetes Care 30 911-917. (doi:10.2337/dc06-1426)

Kapoor D, Clark S, Stanworth R, Channer KS \& Jones TH 2007b The effects of testosterone replacement therapy on adipocytokines and C-reactive protein in hypogonadal men with type 2 diabetes. European Journal of Endocrinology 156 595-602. (doi:10.1530/EJE-06-0737)

Keating NL, O’Malley AJ \& Smith MR 2006 Diabetes and cardiovascular disease during androgen deprivation therapy for prostate cancer. Journal of Clinical Oncology 24 4448-4456. (doi:10.1200/JCO.2006. 06.2497)

Kelley DE \& Mandarino LJ 2000 Fuel selection in human skeletal muscle in insulin resistance: a reexamination. Diabetes 49 677-683. (doi:10.2337/ diabetes.49.5.677)

Kelly DM, Akhtar S, Brooke JC, Muraleedharan V, Channer KS \& Jones TH 2012 Testosterone increases hepatic liver $\mathrm{X}$ receptor and ApoE expression and improves lipid metabolism in the testicular feminized mouse: a potential protective mechanism against atherosclerosis and fatty liver disease. Endocrine Reviews 33 OR22-OR25.

Kahn SE, Hull RL \& Utzschneider KM 2006 Mechanisms linking obesity to insulin resistance and type 2 diabetes. Nature $\mathbf{4 4 4} 840-846$. (doi:10.1038/nature05482)

Khaw KT, Dowsett M, Folkerd E, Bingham S, Wareham N, Luben R, Welch A \& Day N 2007 Endogenous testosterone and mortality due to all causes, cardiovascular disease, and cancer in men: European prospective investigation into cancer in Norfolk (EPIC-Norfolk) Prospective Population Study. Circulation 116 2694-2701. (doi:10.1161/CIRCULATIONAHA.107.719005)

Kiel DP, Baron JA, Plymate SR \& Chute CG 1989 Sex hormones and lipoproteins in men. American Journal of Medicine 87 35-39. (doi:10.1016/S0002-9343(89)80480-2)

Kley HK, Nieschlag E, Wiegelmann W, Solbach HG \& Krüskemper HL 1975 Steroid hormones and their binding in plasma of male patients with fatty liver, chronic hepatitis and liver cirrhosis. Acta Endocrinologica 79 275-285.
Knudsen J, Jensen MV, Hansen JK, Faergeman NJ, Neergaard TB \& Gaigg B 1999 Role of acyl-CoA binding protein in acyl-CoA transport, metabolism and cell signaling. Molecular and Cellular Biochemistry 192 95-103. (doi:10.1023/A:1006830606060)

Krakoff J, Funahashi T, Stehouwer CD, Schalkwijk CG, Tanaka S, Matsuzawa Y, Kobes S, Tataranni PA, Hanson RL, Knowler WC et al. 2003 Inflammatory markers, adiponectin and the risk of type 2 diabetes in the Pima Indians. Diabetes Care 26 1745-1751. (doi:10.2337/diacare. 26.6.1745)

Kupelian V, Page ST, Araujo AB, Travison TG, Bremner WJ \& McKinlay JB 2006 Low sex hormone-binding globulin, total testosterone, and symptomatic androgen deficiency are associated with development of the metabolic syndrome in non-obese men. Journal of Clinical Endocrinology and Metabolism 91 843-850. (doi:10.1210/jc.2005-1326)

Laaksonen DE, Niskanen L, Punnonen K, Nyyssonen K, Tuomainen TP, Valkonen VP, Salonen R \& Salonen JT 2004 Testosterone and sex hormone-binding globulin predict the metabolic syndrome and diabetes in middle-aged men. Diabetes Care 27 1036-1041. (doi:10.2337/diacare.27.5.1036)

Laaksonen DE, Niskanen L, Punnonen K, Nyyssonen K, Tuomainen TP, Valkonen VP \& Salonen JT 2005 The metabolic syndrome and smoking in relation to hypogonadism in middle-aged men: a prospective cohort study. Journal of Clinical Endocrinology and Metabolism 90 712-719. (doi:10.1210/jc.2004-0970)

Lanfranco F, Zitzmann M, Simoni M \& Nieschlag E 2004 Serum adiponectin levels in hypogonadal males: influence of testosterone replacement therapy. Clinical Endocrinology 60 500-507. (doi:10.1111/ j.1365-2265.2004.02007.x)

Leonard SL 1952 The effect of castration and testosterone propionate injection on glycogen storage in skeletal muscle. Endocrinology $\mathbf{5 1}$ 293-297. (doi:10.1210/endo-51-4-293)

Levine GN, D'Amico AV, Berger P, Clark PE, Eckel RH, Keating NL, Milani RV, Sagalowsky AI, Smith MR \& Zakai N 2010 Androgen deprivation therapy in prostate cancer and cardiovascular risk: a science advisory from the American Heart Association, American Cancer Society and American Urological Association: endorsed by the American Society for Radiation Oncology. Circulation 121 833-840. (doi:10.1161/CIRCULATIONAHA.109.192695)

Lim S, Son KR, Song IC, Park HS, Jin CJ, Jang HC, Park KS, Kim YB \& Lee HK 2008 Fat in liver/muscle correlates more strongly with insulin sensitivity in rats than abdominal fat. Obesity 17 188-195. (doi:10.1038/oby.2008.486)

Lin HY, Yu IC, Wang RS, Chen YT, Liu NC, Altuwaijri S, Hsu CL, Ma WL, Jokinen J, Sparks JD et al. 2008 Increased hepatic steatosis and insulin resistance in mice lacking hepatic androgen receptor. Hepatology $\mathbf{4 7}$ 1924-1935. (doi:10.1002/hep.22252)

Macotela Y, Boucher J, Tran TT \& Kahn CR 2009 Sex and depot differences in adipocyte insulin sensitivity and glucose metabolism. Diabetes $\mathbf{5 8}$ 803-812. (doi:10.2337/db08-1054)

Maggio M, Basaria S, Ble A, Lauretani F, Bandinelli S, Ceda GP, Valenti G, Ling SM \& Ferrucci L 2006 Correlation between testosterone and the inflammatory marker soluble interleukin-6 receptor in older men. Journal of Clinical Endocrinology and Metabolism 91 345-347. (doi:10.1210/jc.2005-1097)

Makhsida N, Shah J, Yan G, Fisch H \& Shabsigh R 2005 Hypogonadism and metabolic syndrome: implications for testosterone therapy. Journal of Urology 174 827-834. (doi:10.1097/01.ju.0000169490.78443.59)

Malkin CJ, Pugh PJ, Morris PD, Kerry KE, Jones RD, Jones TH \& Channer KS 2004a Testosterone replacement in hypogonadal men with angina improves ischaemic threshold and quality of life. Heart 90 871-876. (doi:10.1136/hrt.2003.021121)

Malkin CJ, Pugh PJ, Jones RD, Kapoor D, Channer KS \& Jones TH 2004b The effect of testosterone replacement on endogenous inflammatory cytokines and lipid profiles in hypogonadal men. Journal of Clinical Endocrinology and Metabolism 89 3313-3318. (doi:10.1210/jc.2003031069) 
Malkin CJ, Jones TH \& Channer KS 2007 The effect of testosterone on insulin sensitivity in men with heart failure. European Journal of Heart Failure 9 44-50. (doi:10.1016/j.ejheart.2006.04.006)

Mantzoros CS 1999 The role of leptin in human obesity and disease: a review of current evidence. Annals of Internal Medicine 130 671-680.

Mårin P \& Arver S 1998 Androgens and abdominal obesity. Baillière's Clinical Endocrinology and Metabolism 12 441-451. (doi:10.1016/S0950351X(98)80191-2)

Mårin P, Krotkiewski M \& Bjorntorp P 1992a Androgen treatment of middle-aged, obese men: effects on metabolism, muscle and adipose tissues. European Journal of Medicine 1 329-336.

Mårin P, Holmang S, Jonsson L, Sjostrom L, Kvist H, Holm G, Lindstedt G \& Bjorntorp P $1992 b$ The effects of testosterone treatment on body composition and metabolism in middle-aged obese men. International Journal of Obesity and Related Metabolic Disorders 16 991-997.

Mårin P, Odén B \& Björntorp P 1995 Assimilation and mobilization of triglycerides in subcutaneous abdominal and femoral adipose tissue in vivo in men: effects of androgens. Journal of Clinical Endocrinology and Metabolism 80 239-243. (doi:10.1210/jc.80.1.239)

Mårin P, Lönn L, Andersson B, Odén B, Olbe L, Bengtsson BA \& Björntorp P 1996 Assimilation of triglycerides in subcutaneous and intraabdominal adipose tissues in vivo in men: effects of testosterone. Journal of Clinical Endocrinology and Metabolism 81 1018-1022. (doi:10.1210/jc.81.3.1018)

Mauras N, Hayes V, Welch S, Rini A, Helgeson K, Dokler M, Veldhuis JD \& Urban RJ 1998 Testosterone deficiency in young men: marked alterations in whole body protein kinetics, strength, and adiposity. Journal of Clinical Endocrinology and Metabolism 83 1886-1892. (doi:10.1210/jc.83.6.1886)

Max SR 1984 Androgen-estrogen synergy in rat levator ani muscle: glucose6-phosphate dehydrogenase. Molecular and Cellular Endocrinology 38 103-107. (doi:10.1016/0303-7207(84)90108-4)

Max SR \& Knudsen JF 1980 Effect of sex hormones on glucose-6-phosphate dehydrogenase in rat levator ani muscle. Molecular and Cellular Endocrinology 17 111-118. (doi:10.1016/0303-7207(80)90123-9)

McInnes KJ, Smith LB, Hunger NI, Saunders PT, Andrew R \& Walker BR 2012 Deletion of the androgen receptor in adipose tissue in male mice elevates retinol binding protein 4 and reveals independent effects on visceral fat mass and on glucose homeostasis. Diabetes 61 1072-1081. (doi:10.2337/db11-1136)

McLaren D, Kelly D, Akhtar S, Channer K \& Jones T 2012 Low testosterone is associated with decreased expression of glut- 4 and hexokinase 2 in muscle of the testicular feminised mouse. Endocrine Abstracts 29 P559.

Morris PD \& Channer KS 2012 Testosterone and cardiovascular disease in men. Asian Journal of Andrology 14 428-435. (doi:10.1038/aja.2012.21)

Moulana M, Lima R \& Reckelhoff JF 2011 Metabolic syndrome, androgens, and hypertension. Current Hypertension Reports 13 158-162. (doi:10.1007/s11906-011-0184-0)

Movérare-Skrtic S, Venken K, Andersson N, Lindberg MK, Svensson J, Swanson C, Vanderschueren D, Oscarsson J, Gustafsson JA \& Ohlsson C 2006 Dihydrotestosterone treatment results in obesity and altered lipid metabolism in orchidectomized mice. Obesity 14 662-672. (doi:10.1038/oby.2006.75)

Muraleedharan V \& Jones TH 2010 Testosterone and the metabolic syndrome. Therapeutic Advances in Endocrinology and Metabolism 1 207-223. (doi:10.1177/2042018810390258)

Muraleedharan V, Marsh H, Channer KS \& Jones TH 2011 Long-term testosterone replacement improves survival in men with type 2 diabetes and hypogonadism. Endocrine Reviews 32 (03_Meeting Abstracts) OR35-2.

Muthusamy T, Murugesan P \& Balasubramanian K 2009 Sex steroids deficiency impairs glucose transporter 4 expression and its translocation through defective Akt phosphorylation in target tissues of adult male rat. Metabolism 58 1581-1592. (doi:10.1016/j.metabol.2009.05.010)

Muthusamy T, Murugesan P, Srinivasan C \& Balasubramanian K 2011 Sex steroids influence glucose oxidation through modulation of insulin receptor expression and IRS-1 serine phosphorylation in target tissues of adult male rat. Molecular and Cellular Biochemistry 352 35-45. (doi:10.1007/s11010-011-0737-1)

Myking O, Aakvaag A \& Digranes O 1987 Androgen-oestrogen imbalance in men with chronic alcoholism and fatty liver. Alcohol and Alcoholism 22 7-15.

Nettleship JE, Pugh PJ, Channer KS, Jones T \& Jones RD 2007 Inverse relationship between serum levels of interleukin- $1 \beta$ and testosterone in men with stable coronary artery disease. Hormone and Metabolic Research 39 366-371. (doi:10.1055/s-2007-976543)

Nielsen TL, Hagen C, Wraae K, Brixen K, Petersen PH, Haug E, Larsen R \& Andersen M 2007 Visceral and subcutaneous adipose tissue assessed by magnetic resonance imaging in relation to circulating androgens, sex hormone-binding globulin, and luteinizing hormone in young men. Journal of Clinical Endocrinology and Metabolism 92 2696-2705. (doi:10.1210/jc.2006-1847)

Nishiyama T, Ishizaki F, Anraku T, Shimura H \& Takahashi K 2005 The influence of androgen deprivation therapy on metabolism in patients with prostate cancer. Journal of Clinical Endocrinology and Metabolism 90 657-660. (doi:10.1210/jc.2004-1611)

Oh J, Barrett-Connor E, Wedick N \& Wingard D 2002 Endogenous sex hormones and the development of type 2 diabetes in older men and women: the Rancho Bernardo Study. Diabetes Care 25 55-60. (doi:10.2337/diacare.25.1.55)

Olorunshola KV, Aliyu OF \& Achie LN 2012 Testosterone and orchidectomy modulates intestinal fluid and glucose transport in Albino Wistar rat. European Journal of Scientific Research 76 281-287.

Ost A, Danielsson A, Lidén M, Eriksson U, Nystrom FH \& Strålfors P 2007 Retinol-binding protein-4 attenuates insulin-induced phosphorylation of IRS1 and ERK1/2 in primary human adipocytes. FASEB Journal 21 3696-3704. (doi:10.1096/fj.07-8173com)

Page ST, Herbst KL, Amory JK, Coviello AD, Anawalt BD, Matsumoto AM \& Bremner WJ 2005 Testosterone administration suppresses adiponectin levels in men. Journal of Andrology 26 85-92.

Parthasarathy C, Renuka VN \& Balasubramanian K 2009 Sex steroids enhance insulin receptors and glucose oxidation in Chang liver cells. Clinica Chimica Acta 399 49-53. (doi:10.1016/j.cca.2008.09.011)

Pecquery R, Leneveu MC \& Giudicelli Y 1988 Influence of androgenic status on the $\alpha 2 / \beta$-adrenergic control of lipolysis in white fat cells: predominant $\alpha 2$-antilipolytic response in testosterone-treatedcastrated hamsters. Endocrinology 122 2590-2596. (doi:10.1210/ endo-122-6-2590)

Pessin JE \& Saltiel AR 2000 Signaling pathways in insulin action: molecular targets of insulin resistance. Journal of Clinical Investigation 106 165-169. (doi:10.1172/JCI10582)

Phillips G 1993 Relationship between serum sex hormones and the glucose-insulin-lipid defect in men with obesity. Metabolism 42 116-120. (doi:10.1016/0026-0495(93)90181-M)

Pitteloud N, Hardin M, Dwyer AA, Valassi E, Yialamas M, Elahi D \& Hayes FJ $2005 a$ Increasing insulin resistance is associated with a decrease in Leydig cell testosterone secretion in men. Journal of Clinical Endocrinology and Metabolism 90 2636-2641. (doi:10.1210/jc.2004-2190)

Pitteloud N, Mootha VK, Dwyer AA, Hardin M, Lee H, Eriksson KF, Tripathy D, Yialamas M, Groop L, Elahi D et al. 2005b Relationship between testosterone levels, insulin sensitivity, and mitochondrial function in men. Diabetes Care 28 1636-1642. (doi:10.2337/diacare. 28.7.1636)

Ramamani A, Aruldhas MM \& Govindarajulu P 1999 Differential response of rat skeletal muscle glycogen metabolism to testosterone and estradiol. Canadian Journal of Physiology and Pharmacology 77 300-304. (doi:10.1139/y99-016)

Ramirez ME, McMurry MP, Wiebke GA, Felten KJ, Ren K, Meikle AW \& Iverius PH 1997 Evidence for sex steroid inhibition of lipoprotein lipase in men: comparison of abdominal and femoral adipose tissue. Metabolism 46 179-185. (doi:10.1016/S0026-0495(97)90299-7) 
Rebuffé-Scrive M, Mårin P \& Björntorp P 1991 Effect of testosterone on abdominal adipose tissue in men. International Journal of Obesity $\mathbf{1 5}$ 791-795.

Reis C, Liberman S, Pompeo AC, Srougi M, Halpern A \& Jacob Filho W 2009 Body composition alterations, energy expenditure and fat oxidation in elderly males suffering from prostate cancer, pre and post orchiectomy. Clinics 64 781-784. (doi:10.1590/S1807-59322009000800012)

Rodriguez A, Muller DC, Metter EJ, Maggio M, Harman SM, Blackman MR \& Andres R 2007 Aging, androgens, and the metabolic syndrome in a longitudinal study of aging. Journal of Clinical Endocrinology and Metabolism 92 3568-3572. (doi:10.1210/jc.2006-2764)

Roseweir AK \& Millar RP 2009 The role of kisspeptin in the control of gonadotrophin secretion. Human Reproduction Update 15 203-212. (doi:10.1093/humupd/dmn058)

Rosignoli C, Nicolas JC, Jomard A \& Michel S 2003 Involvement of the SREBP pathway in the mode of action of androgens in sebaceous glands in vivo. Experimental Dermatology 12 480-489. (doi:10.1034/j.16000625.2003.00014.x)

Saad F, Gooren L, Haider A \& Yassin A 2007 An exploratory study of the effects of 12 month administration of the novel long-acting testosterone undecanoate on measures of sexual function and the metabolic syndrome. Archives of Andrology 53 353-357. (doi:10.1080/ 01485010701730880)

Saad F, Gooren LJ, Haider A \& Yassin A 2008 A dose-response study of testosterone on sexual dysfunction and features of the metabolic syndrome using testosterone gel and parenteral testosterone undecanoate. Journal of Andrology 29 102-105. (doi:10.2164/jandrol.107. 002774)

Saad F, Aversa A, Isidori AM \& Gooren LJ 2012 Testosterone as potential effective therapy in treatment of obesity in men with testosterone deficiency: a review. Current Diabetes Reports 8 131-143. (doi:10.2174/ 157339912799424573)

Salam R, Kshetrimayum AS \& Keisam R 2012 Testosterone and metabolic syndrome: the link. Indian Journal of Endocrinology and Metabolism 16(Suppl 1) S12-S19. (doi:10.4103/2230-8210.94248)

Salehzadeh F, Rune A, Osler M \& Al-Khalili L 2011 Testosterone or $17 \beta$-estradiol exposure reveals sex-specific effects on glucose and lipid metabolism in human myotubes. Journal of Endocrinology 210 219-229. (doi:10.1530/JOE-10-0497)

Sansone G, Davidson W, Cummings B \& Reisner RM 1971 Sebaceous gland lipogenesis induced by testosterone: early metabolic events. Journal of Investigative Dermatology 57 144-148. (doi:10.1111/1523-1747. ep12261491)

Santosa S \& Jensen MD 2012 Effects of male hypogonadism on regional adipose tissue fatty acid storage and lipogenic proteins. PLOS ONE 7 e31473. (doi:10.1371/journal.pone.0031473)

Sato K, Iemitsu M, Aizawa K \& Ajisaka R 2008 Testosterone and DHEA activate the glucose metabolism-related signaling pathway in skeletal muscle. American Journal of Physiology. Endocrinology and Metabolism 294 E961-E968. (doi:10.1152/ajpendo.00678.2007)

Schuster DP 2010 Obesity and the development of type 2 diabetes: the effects of fatty tissue inflammation. Diabetes, Metabolic Syndrome and Obesity: Targets and Therapy 3 253-262. (doi:10.2147/DMSOTT.S7354)

Seidell JC, Bjorntorp P, Sjostrom L, Kvist H \& Sannerstedt R 1990 Visceral fat accumulation in men is positively associated with insulin, glucose, and C-peptide levels, but negatively with testosterone levels. Metabolism 39 897-901. (doi:10.1016/0026-0495(90)90297-P)

Selvin E, Feinleib M, Zhang L, Rohrmann S, Rifai N, Nelson WG, Dobs A, Basaria S, Golden SH \& Platz EA 2007 Androgens and diabetes in men. Results from the Third National Health and Nutrition Examination Survey (NHANES III). Diabetes Care 30 234-238. (doi:10.2337/ dc06-1579)

Sesti G, Marini MA, Briata P, Tullio AN, Montemurro A, Borboni P, De Pirro R, Gherzi R \& Lauro R 1992 Androgens increase insulin receptor mRNA levels, insulin binding, and insulin responsiveness in
HEp-2 larynx carcinoma cells. Molecular and Cellular Endocrinology 86 111-118. (doi:10.1016/0303-7207(92)90181-5)

Shabsigh R, Arver S, Channer KS, Eardley I, Fabbri A, Gooren L, Heufelder A, Jones H, Meryn S \& Zitzmann M 2008 The triad of erectile dysfunction, hypogonadism and the metabolic syndrome. International Journal of Clinical Practice 62 791-798. (doi:10.1111/j.1742-1241.2008.01696.x)

Shahani S, Braga-Basaria M \& Basaria S 2008 Androgen deprivation therapy in prostate cancer and metabolic risk for atherosclerosis. Journal of Clinical Endocrinology and Metabolism 93 2042-2049. (doi:10.1210/ jc.2007-2595)

Shoelson SE, Lee J \& Goldfine AB 2006 Inflammation and insulin resistance. Journal of Clinical Investigation 116 1793-1801. (doi:10.1172/ JCI29069)

Shores MM, Smith NL, Forsberg CW, Anawalt BD \& Matsumoto AM 2012 Testosterone treatment and mortality in men with low testosterone levels. Journal of Clinical Endocrinology and Metabolism 97 2050-2058. (doi:10.1210/jc.2011-2591)

Simon D, Charles MA, Nahoul K, Orssaud G, Kremski J, Hully V, Joubert E, Papoz L \& Eschwege E 1997 Association between plasma total testosterone and cardiovascular risk factors in healthy adult men: the Telecom Study. Journal of Clinical Endocrinology and Metabolism $\mathbf{8 2}$ 682-685. (doi:10.1210/jc.82.2.682)

Singh AB, Hsia S, Alaupovic P, Sinha-Hikim I, Woodhouse L, Buchanan TA, Shen R, Bross R, Berman N \& Bhasin S 2002 The effects of varying doses of $\mathrm{T}$ on insulin sensitivity, plasma lipids, apolipoproteins, and C-reactive protein in healthy young men. Journal of Clinical Endocrinology and Metabolism 87 136-143. (doi:10.1210/jc.87.1.136)

Smith JC, Bennett S, Evans LM, Kynaston HG, Parmar M, Mason MD, Cockcroft JR, Scanlon MF \& Davies JS 2001 The effects of induced hypogonadism on arterial stiffness, body composition, and metabolic parameters in males with prostate cancer. Journal of Clinical Endocrinology and Metabolism 86 4261-4267. (doi:10.1210/jc.86.9.4261)

Smith MR, Finkelstein JS, McGovern FJ, Zietman AL, Fallon MA, Shoenfeld DA \& Kantoff PW 2002 Changes in body composition during androgen deprivation therapy for prostate cancer. Journal of Clinical Endocrinology and Metabolism 87 599-603. (doi:10.1210/jc.87.2.599)

Smith MR, Lee H \& Nathan DM 2006 Insulin sensitivity during combined androgen blockade for prostate cancer. Journal of Clinical Endocrinology and Metabolism 91 1305-1308. (doi:10.1210/jc.2005-2507)

Spranger J, Kroke A, Möhlig M, Bergmann MM, Ristow M, Boeing H \& Pfeiffer AF 2003 Adiponectin and protection against type 2 diabetes. Lancet 361 226-228. (doi:10.1016/S0140-6736(03)12255-6)

Srikanthan P \& Karlamangla AS 2011 Relative muscle mass is inversely associated with insulin resistance and prediabetes. Findings from the Third National Health and Nutrition Examination Survey. Journal of Clinical Endocrinology and Metabolism 96 2898-2903. (doi:10.1210/ jc.2011-0435)

Stanworth RD \& Jones TH 2009 Testosterone in obesity, metabolic syndrome and type 2 diabetes. Frontiers of Hormone Research 37 74-90.

Stanworth RD, Kapoor D, Channer KS \& Jones TH 2008 Androgen receptor CAG repeat polymorphism is associated with serum testosterone levels, obesity and serum leptin in men with type 2 diabetes. European Journal of Endocrinology 159 736-746. (doi:10.1530/EJE-08-0266)

Stanworth RD, Kapoor D, Channer KS \& Jones TH 2011 Dyslipidaemia is associated with testosterone, oestradiol and androgen receptor CAG repeat polymorphism in men with type 2 diabetes. Clinical Endocrinology 74 624-630. (doi:10.1111/j.1365-2265.2011.03969.x)

Stellato RK, Feldman HA, Hamdy O, Horton ES \& McKinlay JB 2000 Testosterone, sex hormone binding globulin and the development of type 2 diabetes in middle aged men. Diabetes Care 23 490-494. (doi:10.2337/diacare.23.4.490)

Stratford S, Hoehn KL, Liu F \& Summers SA 2004 Regulation of insulin action by ceramide: dual mechanisms linking ceramide accumulation to the inhibition of Akt/protein kinase B. Journal of Biological Chemistry 279 36608-36615. (doi:10.1074/jbc.M406499200) 
Stumvoll M, Jacob S, Wahl HG, Hauer B, Löblein K, Grauer P, Becker R, Nielsen M, Renn W \& Häring H 2000 Suppression of systemic, intramuscular, and subcutaneous adipose tissue lipolysis by insulin in humans. Journal of Clinical Endocrinology and Metabolism 85 3740-3745. (doi:10.1210/jc.85.10.3740)

Su CL, Huang HY, Shen ZQ \& Lin JF 2009 The effects of testosterone on the expression of inflammatory factors in 3T3-L1 adipocytes and its mechanism. Zhonghua Yi Xue Za Zhi 89 1493-1497.

Svartberg J, Agledahl I, Figenschau Y, Sildnes T, Waterloo K \& Jorde R 2008 Testosterone treatment in elderly men with subnormal testosterone levels improves body composition and BMD in the hip. International Journal of Impotence Research 20 378-387. (doi:10.1038/ijir.2008.19)

Swinnen JV \& Verhoeven G 1998 Androgens and the control of lipid metabolism in human prostate cancer cells. Journal of Steroid Biochemistry and Molecular Biology 65 191-198. (doi:10.1016/S0960-0760(97)00187-8)

Swinnen JV, Van Veldhoven PP, Esquenet M, Heyns W \& Verhoeven G 1996 Androgens markedly stimulate the accumulation of neutral lipids in the human prostatic adenocarcinoma cell line LNCaP. Endocrinology 137 4468-4474. (doi:10.1210/en.137.10.4468)

Swinnen JV, Ulrix W, Heyns W \& Verhoeven G 1997 Coordinate regulation of lipogenic gene expression by androgens: evidence for a cascade mechanism involving sterol regulatory element binding proteins. PNAS 94 12975-12980. (doi:10.1073/pnas.94.24.12975)

Thompson PD, Cullinane EM, Sady SP, Chenevert C, Saritelli AL, Sady MA \& Herbert PN 1989 Contrasting effects of testosterone and stanozolol on serum lipoprotein levels. Journal of the American Medical Association 261 1165-1168. (doi:10.1001/jama.1989.03420080085036)

Traish AM, Guay A, Feeley R \& Saad F 2009 The dark side of testosterone deficiency: I. Metabolic syndrome and erectile dysfunction. Journal of Andrology 30 10-22. (doi:10.2164/jandrol.108.005215)

Tsai EC, Boyko EJ, Leonetti DL \& Fujimoto WY 2000 Low serum testosterone level as a predictor of increased visceral fat in JapaneseAmerican men. International Journal of Obesity and Related Metabolic Disorders 24 485-491. (doi:10.1038/sj.ijo.0801183)

Uyanik BS, Ari Z, Gümüs B, Yiğitoğlu MR \& Arslan T 1997 Beneficial effects of testosterone undecanoate on the lipoprotein profiles in healthy elderly men. A placebo controlled study. Japanese Heart Journal $\mathbf{3 8}$ 73-82. (doi:10.1536/ihj.38.73)

Van Pottelbergh I, Braeckman L, De Bacquer D, De Backer G \& Kaufman JM 2003 Differential contribution of testosterone and estradiol in the determination of cholesterol and lipoprotein profile in healthy middle-aged men. Atherosclerosis 166 95-102. (doi:10.1016/S0021-9150(02)00308-8)

Vikan T, Schirmer H, Njølstad I \& Svartberg J 2009 Endogenous sex hormones and the prospective association with cardiovascular disease and mortality in men: the Troms $\varnothing$ Study. European Journal of Endocrinology 161 435-442. (doi:10.1530/EJE-09-0284)

Völzke H, Aumann N, Krebs A, Nauck M, Steveling A, Lerch MM, Rosskopf D \& Wallaschofski H 2010 Hepatic steatosis is associated with low serum testosterone and high serum DHEAS levels in men. International Journal of Andrology 33 45-53. (doi:10.1111/j.1365-2605.2009.00953.x)

Wang C, Swerdloff RS, Iranmanesh A, Dobs A, Snyder PJ, Cunningham G, Matsumoto AM, Weber T, Berman N \& Testosterone Gel Study Group 2000 Transdermal testosterone gel improves sexual function, mood, muscle strength and body composition parameters in hypogonadal men. Journal of Clinical Endocrinology and Metabolism 85 2839-2853. (doi:10.1210/jc.85.8.2839)
Wang C, Jackson G, Jones TH, Matsumoto AM, Nehra A, Perelman MA, Swerdloff RS, Traish A, Zitzmann M \& Cunningham G 2011 Low testosterone associated with obesity and the metabolic syndrome contributes to sexual dysfunction and cardiovascular disease risk in men with type 2 diabetes. Diabetes Care 34 1669-1675. (doi:10.2337/dc10-2339)

Wei Y, Chen K, Whaley-Connell AT, Stump CS, Ibdah JA \& Sowers JR 2007 Skeletal muscle insulin resistance: role of inflammatory cytokines and reactive oxygen species. American Journal of Physiology: Regulatory, Integrative and Comparative Physiology 294 R673-R680. (doi:10.1152/ ajpregu.00561.2007)

Whitsel EA, Boyko EJ, Matsumoto AM, Anawalt BD \& Siscovick DS 2001 Intramuscular testosterone esters and plasma lipids in hypogonadal men: a meta-analysis. American Journal of Medicine 111 261-269. (doi:10.1016/S0002-9343(01)00833-6)

Woodhouse LJ, Gupta N, Bhasin M, Singh AB, Ross R, Phillips J \& Bhasin S 2004 Dose-dependent effects of testosterone on regional adipose tissue distribution in healthy young men. Journal of Clinical Endocrinology and Metabolism 89 718-726. (doi:10.1210/jc.2003-031492)

Wu FC \& von Eckardstein A 2003 Androgens and coronary artery disease. Endocrine Reviews 24 183-217. (doi:10.1210/er.2001-0025)

Xie P, Liu ML, Gu YP, Lu J, Xu X, Zeng WM \& Song HP 2003 Oestrogen improves glucose metabolism and insulin signal transduction in HepG 2 cells. Clinical and Experimental Pharmacology \& Physiology 30 643-648. (doi:10.1046/j.1440-1681.2003.03899.x)

Yanase T, Fan W, Kyoya K, Min L, Takayanagi R, Kato S \& Nawata H 2008 Androgens and metabolic syndrome: lessons from androgen receptor knock out (ARKO) mice. Journal of Steroid Biochemistry and Molecular Biology 109 254-257. (doi:10.1016/j.jsbmb.2008.03.017)

Yang Q, Graham TE, Mody N, Preitner F, Peroni OD, Zabolotny JM, Kotani K, Quadro L \& Kahn BB 2005 Serum retinol binding protein 4 contributes to insulin resistance in obesity and type 2 diabetes. Nature $\mathbf{4 3 6} 356-362$. (doi:10.1038/nature03711)

Yannucci J, Manola J, Garnick MB, Bhat G \& Bubley GJ 2006 The effect of androgen deprivation therapy on fasting serum lipid and glucose parameters. Journal of Urology 176 520-525. (doi:10.1016/j.juro.2006.03.057)

Yassin AA, Saad F \& Gooren LJ 2008 Metabolic syndrome, testosterone deficiency and erectile dysfunction never come alone. Andrologia 40 259-264. (doi:10.1111/j.1439-0272.2008.00851.x)

Yu YH \& Ginsberg HN 2005 Adipocyte signaling and lipid homeostasis: sequelae of insulin-resistant adipose tissue. Circulation Research 96 1042-1052. (doi:10.1161/01.RES.0000165803.47776.38)

Zgliczynski S, Ossowski M, Slowinska-Srzednicka J, Brzezinska A, Zgliczynski W, Soszynski P, Chotkowska E, Srzednicki M \& Sadowski Z 1996 Effect of testosterone replacement therapy on lipids and lipoproteins in hypogonadal and elderly men. Atherosclerosis 121 35-43. (doi:10.1016/0021-9150(95)05673-4)

Zitzmann M 2009a Testosterone deficiency, insulin resistance and the metabolic syndrome. Nature Reviews. Endocrinology 5 673-681. (doi:10.1038/nrendo.2009.212)

Zitzmann M $2009 b$ The role of the CAG repeat androgen receptor polymorphism in andrology. Frontiers of Hormone Research 37 52-61.

Zitzmann M \& Nieschlag E 2007 Androgen receptor gene CAG repeat length and body mass index modulate the safety of long-term intramuscular testosterone undecanoate therapy in hypogonadal men. Journal of Clinical Endocrinology and Metabolism 92 3844-3853. (doi:10.1210/jc.2007-0620)

Received in final form 24 December 2012

Accepted 30 January 2013

Accepted Preprint published online 30 January 2013 http://joe.endocrinology-journals.org DOI: $10.1530 / \mathrm{JOE}-12-0455$
() 2013 Society for Endocrinology Printed in Great Britain 